\title{
Estimating the Effects of Fiscal Policy IN OECD COUNTRIES
}

\section{Roberto Perotti}

CEPS Working Documents are published to give an indication of the work within CEPS' various research programmes and to stimulate reactions from other experts in the field. Unless otherwise indicated, the views expressed are attributable only to the author in a personal capacity and not to any institution with which he is associated.

ISBN 92-9079-402-X

Available for free downloading from the CEPS website (http://www.ceps.be)

(C) Copyright 2002, CEPS 


\title{
Estimating the effects of fiscal policy in OECD countries
}

\author{
Roberto Perotti* \\ First version: June 2002 \\ This revision: September 2002
}

\begin{abstract}
This paper studies the effects of fiscal policy on GDP, prices and interest rates in 5 OECD countries, using a structural Vector Autoregression approach. Its main results can be summarized as follows: 1) The estimated effects of fiscal policy on GDP tend to be small: positive government spending multipliers larger than 1 tend to be the exception; 2) The effects of fiscal policy on GDP and its components have become substantially weaker over time; 3) Under plausible values of the price elasticity, government spending has positive effects on the price level, although usually small; 4) Government spending shocks have significant effects on the nominal and real short interest rate, but of varying signs; 5) In the post-1980 period, net tax shocks have positive short run effects on the nominal interest rate, and typically negative or zero effects on prices; 6) The US is an outlier in many dimensions; responses to fiscal shocks estimated on US data are often not representative of the average OECD country included in this sample.
\end{abstract}

*European University Institute and Centre for Economic Policy Research. This paper was prepared for the ISOM conference, Frankfurt, June 14-15 2002. I thank the editor, Jim Stock, and three anonymous referees for comments that led to a substantial improvement in the paper. I thank Jordi Galí, Daniel Gros, and Ilian Mihov for helpful conversations. My discussants, Zvi Eckstein and Jon Faust, and several other conference participants also made very useful suggestions. This project has evolved out of an initial collaboration with Olivier Blanchard, from whom I have learnt a great deal. André Meier and Luca Onorante provided excellent research assistance. I also thank Kathie Whiting of the Australian Bureau of Statistics for help with the Australian data and Bill Roberts of the Office of National Statistics for help with the British data. 


\title{
Estimating the effects of fiscal policy in OECD countries
}

\author{
Roberto Perotti
}

\section{Introduction}

While most economists would agree that an exogenous 10 percent increase in money supply will lead to some increase in prices after a while, perfectly reasonable economists can and do disagree even on the sign of the response of private consumption or private investment to an exogenous shock to government purchases of goods. Yet, there is no doubt that many more resources have been devoted to the study of monetary policy than fiscal policy; only recently has a small but growing literature emerged that applies to fiscal policy time series methods that have long been standard in the analysis of monetary policy. ${ }^{1}$

One reason why relatively little empirical work has been done on the effects of fiscal policy is probably the difficulty in assembling the necessary data at high enough frequency and over sufficiently long periods. In this paper, I present evidence on the effects of fiscal policy in five countries for which I was able to assemble sufficiently detailed quarterly data on the budget of the general government: the US, West Germany, the UK, Canada, and Australia. I do so using an approach originally developed in Blanchard and Perotti [2002]: in essence, the method exploits institutional features of fiscal policymaking and detailed information on the automatic effects of GDP and inflation on tax revenues and government spending to identify the exogenous fiscal policy shocks in a structural vector autoregression.

Beside including more countries, this paper extends the methodology of Blanchard and Perotti [2002] to study the interaction of fiscal and monetary policy, and the effects of fiscal policy on prices. Recent developments both in the theory and in the practice of monetary policy have also emphasized the link between fiscal and monetary policy. At the policy level, many of the institutional provisions of the EMU have been rationalized in terms of constraints on fiscal policy to enable monetary policy to achieve its mandate

\footnotetext{
${ }^{1} \mathrm{I}$ review this literature in the next section. Almost all the recent empirical literature refers to the United States. The exceptions known to me are Favero [2002] and Marcellino [2002], who estimate fiscal policy VARs using half-yearly data from four European countries: France, Italy, Spain, and Germany.
} 
of price stability. And several policy measures, like the EU Council of Ministers's reprimand against Ireland in February 2001, have been motivated by the alleged affects of specific fiscal policy actions on inflation and interest rates. At the academic level, research on the Taylor rule has inevitably run into the issue of how fiscal policy might interfere with interest rate control (see Taylor [1996], Taylor [2000], and Woodford [1999]); more generally, the fiscal theory of the price level has emphasized the potential links between fiscal policy and the price level (see, among others, Cochrane [2001], Sims [1994] and [1999], and Woodford [2001]). ${ }^{2}$

The main conclusions of the analysis can be summarized as follows: 1) The estimated effects of fiscal policy on GDP tend to be small: positive government spending multipliers larger than 1 tend to be the exception; the tax multipliers are usually negative but even smaller in absoulte value; 2) The effects of fiscal policy on GDP and its components have become substantially weaker over time: in the post-1980 period significantly negative multipliers of government spending are the norm; the negative effects of taxation have also become weaker; 3) To understand the effects of fiscal policy on prices, the price elasticity of the government budget items is crucial, an issue that has not been widely appreciated. Once Once plausible values of the price elasticity of government spending are imposed, the negative effects of government spending on prices that have been frequently estimated become positive, although usually small and not always significant; 4) Government spending shocks have significant effects on the nominal and real short interest rate, but of varying signs: in the post-1980 period, after 4 quarters the effect is positive in three countries, negative in two; 5) In the post-1980 period, net tax shocks have positive short run effects on the nominal interest rate, and typically negative or zero effects on prices; 6 ) The US is an outlier in many dimensions; responses to fiscal shocks estimated on US data are often not representative of the average OECD country included in this sample. ${ }^{3}$

The plan of the paper is as follows. Section 2 briefly reviews alternative approaches that have been used to identify fiscal shocks in VARs and the methodology I use. Section 3 describes the data and how the elasticities of government spending and taxes to economic activity are constructed. Section 4 briefly discusses a few diagnostic checks on the estimated VARs. The

\footnotetext{
${ }^{2}$ The evidence presented in this paper, however, has nothing to say on the fiscal theory of the price level. By its nature, the theory places no testable restriction on the observed relation between fiscal variables and the price level.

${ }^{3}$ It is well understood, but still worth repeating, that the results presented here have nothing to say about the effects of systematic fiscal policy as a stabilizing tool, an issue a VAR by its nature is ill equipped to address. See Jones [2002] for an interesting analysis of this issue.
} 
estimated effects of government spending on GDP and the short interest rate are presented in Section 5. Section 6 discusses the effects of government spending shocks on GDP components. Section 7 discusses the rationale for and consequences of including interest rates in the VAR. Section 8 presents the price responses to government spending shocks. Section 9 displays the results of a tax shock on GDP, interest rate and prices. Section 10 concludes. An appendix provides further details on the construction of the tax elasticities.

\section{The fiscal shocks}

\subsection{Approaches to identification}

A small but growing literature has recently applied VAR methods to the analysis of fiscal policy In this section, I briefly review the four different approaches to identification of fiscal policy shocks that have been used. ${ }^{4}$

(i) In a first group, represented by Burnside, Eichenbaum and Fisher [2001], Christiano, Eichenbaum and Eidelberg [1999] , and Ramey and Shapiro [1998], fiscal policy shocks are identified by way of the "narrative approach" of Romer and Romer [1989]. All these papers trace the effects of a dummy variable capturing the "Ramey and Shapiro" fiscal episodes: the Korean war military buildup, the Vietnam war buildup, and the Reagan fiscal expansion.

The advantages and disadvantages of this approach are well known. If these episodes are truly exogenous and unanticipated, and one is only interested in estimating their effects, there is no need to impose other potentially controversial identifying assumptions: all is needed is a reduced form regression. But the approach might run into two types of problems. First, these episodes might not be entirely unanticipated. Second, other substantial fiscal shocks, of different type or sign, might have occurred around the same time, thus polluting the identification of the fiscal shocks. ${ }^{5}$

(ii) A second approach, represented by Mountford and Uhlig [2002], consists in identifying fiscal shocks by sign restrictions on the impulse responses, following a methodology originally applied by Uhlig [1997] and Faust [1998]

\footnotetext{
${ }^{4}$ This brief review is based on the papers known to me at the time of writing. I apologize for involuntary omissions of relevant contributions.

${ }^{5}$ For instance, Ramey and Shapiro date the start of the Korean war shock in 1950:3, based on the large observed increase in military spending; but net tax revenues also increased by more than three standard deviations in 1950:2 and 1950:3; and in four quarters between 1948:2 and 1950:3, government spending increased by between two and three standard deviations. It is not obvious how to disentangle the effects of the Korean dummy variable from the delayed effects of these preceding fiscal shocks.
} 
to monetary policy analysis. For instance, "revenue" shocks are identified by imposing that tax revenue response increases while the government spending response does not, and that all responses such that both tax revenues and GDP increase identify a business cycle shock.

An important advantage of this approach is that it is well suited to handle anticipated fiscal shocks: the estimated effect on, say, private consumption at time 0 could be the response to a revenue shock that occurs later. On the other hand, by identifying revenue shocks via the condition that tax revenues and output do not covary positively in response to the shock, the approach rules out by assumption a whole set of "non-keynesian" output responses to fiscal shocks. ${ }^{6}$ A second cost of this approach is also related to its benefits: while it can better handle anticipated fiscal policy, it cannot pin down when the fiscal shock occurs.

(iii) A third approach, represented by Fatas and Mihov [2001] and Favero [2002], essentially relies on Choleski ordering to identify fiscal shocks. In the former, government spending is ordered first: in the latter, fiscal shocks are ordered last, by analogy to monetary shocks in some recent monetary policy VAR contributions. A discussion of this approach will be implicit in the discussion of the next one.

(iv) The fourth approach, developed by Blanchard and Perotti [2002], is akin to a structural VAR. ${ }^{7}$ Identification is achieved by exploiting decision lags in fiscal policy, and institutional information about the elasticity of fiscal variables to economic activity. In this paper, I extend this approach to take into account interest rates and inflation. ${ }^{8}$

Consider the benchmark specification, a 5-variable VAR that includes the following variables: the log of real government spending on goods and services per capita $g_{t}$ (government spending for short), the log of real net primary taxes per capita (defined as government revenues less government transfers, both net of property income) $t_{t}$, the log of real output per capita $y_{t}$, the log of the price level $p_{t}$, and the 3 -month nominal interest rate $i_{t} \cdot{ }^{9}$ Denoting

\footnotetext{
${ }^{6}$ For some empirical evidence on non-Keynesian effects of fiscal policy, see Alesina et al. [2002], Giavazzi, Jappelli and Pagano [2000], and Perotti [1999]. Other shocks in teh Mountford and Uhlig [2002] approach, like spending shocks, are identified with a minimal set of restrictions, involving only the behavior of government spending and taxation.

${ }^{7}$ An early application of this approach is Blanchard and Watson [1986].

${ }^{8}$ At the same time as this paper was being written, Canzoneri, Cumby and Diba [2002] also extended the Blanchard and Perotti [2002] methodology to include inflation and interest rate responses to the analysis of US fiscal policy. Instead of bringing in external information on the elasticities of fiscal variables to economic activity, Marcellino [2002] estimates these elasticities by specifiying a larger model with overidentifying restrictions.

${ }^{9}$ This two-way breakdown of the government budget is obviously only one of many possible. Most models would predict that government spending on goods and services has
} 
the vector of endogenous variables by $X_{t}$ and the vector of reduced form residuals by $U_{t}$, the reduced form VAR can be written as:

$$
X_{t}=A(L) X_{t-1}+U_{t}
$$

where $X_{t} \equiv\left[\begin{array}{lllll}g_{t} & t_{t} & y_{t} & p_{t} & i_{t}\end{array}\right]^{\prime}$ and $U_{t} \equiv\left[\begin{array}{lllll}u_{t}^{g} & u_{t}^{t} & u_{t}^{y} & u_{t}^{p} & u_{t}^{i}\end{array}\right]^{\prime}$.

The reduced form residuals of the $g_{t}$ and $t_{t}$ equations, $u_{t}^{g}$ and $u_{t}^{t}$, can be thought of as the sum of the automatic and discretionary shocks to government spending and net taxes, respectively. Taxes and, to a lesser degree, government spending react automatically to shocks in the other endogenous variables, for instance because of the automatic increase in tax revenues when output increases, holding constant tax rates. Taxes and government spending can also be changed in a discretionary way by the policymaker, for instance by changing the tax rates themselves. Formally, one can write the reduced form government spending and net tax residuals as

$$
\begin{aligned}
u_{t}^{t} & =\alpha_{t y} u_{t}^{y}+\alpha_{t p} u_{t}^{p}+\alpha_{t i} u_{t}^{i}+\beta_{t g} e_{t}^{g}+e_{t}^{t} \\
u_{t}^{g} & =\alpha_{g y} u_{t}^{y}+\alpha_{g p} u_{t}^{p}+\alpha_{g i} u_{t}^{i}+\beta_{g t} e_{t}^{t}+e_{t}^{g}
\end{aligned}
$$

where $e_{t}^{g}$ and $e_{t}^{t}$ are the "structural" shocks to government spending and taxes, part of the vector of mutually uncorrelated "structural" shocks $F_{t} \equiv$ $\left[\begin{array}{lllll}e_{t}^{g} & e_{t}^{t} & e_{t}^{x} & e_{t}^{p} & e_{t}^{i}\end{array}\right]^{\prime}$. The key to identification is the observation that it typically takes longer than three months to decide a discretionary change in fiscal policy; as a consequence, in quarterly data the coefficients $\alpha_{j k}^{\prime} \mathrm{s}$ in (2) reflect only the automatic response of fiscal variables to economic activity, and $e_{t}^{g}$ and $e_{t}^{t}$ can be interpreted as the discretionary components of the fiscal policy reduced form residuals.

Identifying $e_{t}^{g}$ and $e_{t}^{t}$ would still not be feasible if one had to estimate the $\alpha_{j k}^{\prime} \mathrm{s}$, because $e_{t}^{g}$ and $e_{t}^{t}$ are correlated with the reduced form residuals on the rhs of (2). However, we do have independent information on the $\alpha_{j k}^{\prime} \mathrm{s}$, whose construction is discussed in detail in the next section. With these values of the $\alpha_{j k}^{\prime} \mathrm{s}$, one can construct linear combinations of the two structural shocks, or the cyclically adjusted fiscal shocks:

$$
\begin{aligned}
u_{t}^{t, C A} & \equiv u_{t}^{t}-\left(\alpha_{t y} u_{t}^{y}+\alpha_{t p} u_{t}^{p}+\alpha_{t i} u_{t}^{i}\right)=\beta_{t g} e_{t}^{g}+e_{t}^{t} \\
u_{t}^{g, C A} & \equiv u_{t}^{g}-\left(\alpha_{g y} u_{t}^{y}+\alpha_{g p} u_{t}^{p}+\alpha_{g i} u_{t}^{i}\right)=\beta_{g t} e_{t}^{t}+e_{t}^{g}
\end{aligned}
$$

different effects than transfers. Summing algebraically taxes and transfers makes sense if one believes that in the short- and medium run fiscal policy operates mostly via a demand channel. In future work, I am planning to study different disaggregations of the government budgets - in particular, government consumption vs government investment, and taxes vs transfers. 
There is still little guidance, theoretical or empirical, on how to sort out the two structural shocks $e_{t}^{t}$ and $e_{t}^{g}$ from the cyclically adjusted fiscal shocks. Therefore, I compute impulse responses under the two alternative orthogonalizations: as it turns out, in all cases the correlation between the two cyclically adjusted fiscal shocks is low enough that the ordering of the structural shocks is immaterial to the results. ${ }^{10}$

Because both $e_{t}^{g}$ and $e_{t}^{t}$ are orthogonal to the other structural shocks of the economy; they can be used as instruments in the remaining equations. ${ }^{11}$

Once the structural shocks are identified, the impulse responses are constructed using the average elasticities over the relevant sample periods.

\subsection{What are the fiscal shocks?}

How to interpret the fiscal policy shocks $e_{t}^{t}$ and $e_{t}^{g}$ ? Government spending is typically budgeted in advance for the whole fiscal year, hence one could argue that the fiscal shocks identified by the methodology above are not really unanticipated. However, the yearly budget is often mostly a political document, whose figures typically bear little relation to the actual expenditure eventually disbursed, and which is discounted by the private sector as such. In addition, even if the total expenditure for the year were fixed and reliable, actual cash disbursements can vary unpredictably on a quarterly basis for a variety of reasons. ${ }^{12}$

More importantly, there are shocks to budgeted expenditure all through the year, due to mid-year legislation and executive decisions. Under this interpretation, however, while as we have seen decision lags in fiscal policymaking help identify the shocks, implementation lags contribute to making them predictable.

Thus, the validity of the identification procedure outlined here is a matter of degree. It depends on how long and predictable the decision lags are relative to the implementation lags, and on how important the yearly budget is relative to quarterly policymaking.

\footnotetext{
${ }^{10}$ Although I consider only the two Choleski orderings of the two cyclically adjusted fiscal variables, one should recognize that, lacking a theory, really any rotation of the two shocks could be defended.

${ }^{11}$ The ordering of the remaining variables is immaterial if one is only interested in estimating the effects of fiscal policy shocks, as it is the case in this paper. Assuming for instance that output is ordered first among the other variables, one can estimate the "output" equation $u_{t}^{y}=\gamma_{y t} u_{t}^{t}+\gamma_{y g} u_{t}^{g}+e_{t}^{y}$, using $e_{t}^{t}$ and $e_{t}^{g}$ as instruments for $u_{t}^{t}$ and $u_{t}^{g}$, and similarly for the other equations.

${ }^{12}$ Strictly speaking, the fiscal policy shock of the last quarter of the fiscal year would be perfectly predictable under these hypotheses.
} 


\section{Specification, samples and data}

\subsection{Specification and samples}

I estimate the VAR specification described in section 2.1on quarterly data from five countries: Australia, Canada, West Germany, United Kingdom, and Unites States. ${ }^{13}$ The benchmark VAR includes the logs of real GDP, real government spending and real net taxes, all in per capita terms, and deflated using the GDP deflator; the log of the GDP deflator; and the nominal 3 months interest rate (the federal funds rate for the US). All variables (except the interest rates) have been seasonally adjusted by the original sources. All equations include four lags of each endogenous variable, a constant, and no time trends. The precise samples of the benchmark VARs are: USA: 1961:1 - 2000:4; West Germany: 1961:1 - 1989:4; United Kingdom: 1964:1 - 2001:2; Canada: 1962:1 - 2001:4; Australia: 1964:1 - 2000:4.

\subsection{The data}

One reason why fiscal policy VARs have been less popular than their monetary policy counterparts is that fiscal policy data at high enough frequency are more difficult to collect; in most countries they simply do not exist. ${ }^{14}$

All the fiscal data used in this paper originate from only one source per country, ensuring internal consistency ${ }^{15}$ in all cases, the fiscal data are part

\footnotetext{
${ }^{13}$ In Blanchard and Perotti [2002], we estimated quarter dependent 3-variable VARs, on the basis that there is some quarter dependence in tax collections. However, we also found that quarter dependence makes little difference for the US. The description of the institutional features of the tax systems in Appendix 1 makes clear that only for corporate income taxes in the United Kingdom is quarter dependence likely to be substantial. Moreover, in the 5 -variable VARs that I estimate in this paper, allowing for quarter dependence would quickly exhaust the available degrees of freedom.

${ }^{14}$ Of the other OECD countries, France, Japan and New Zealand seem to have quarterly general government budget figures for long enough periods. However, it appears that parts of the budget data of these countries might be interpolated from annual figures. I am currently investigating the nature of the data for these countries.

Other countries have some quarterly or even monthly data on some parts of the budget, or covering only the central government accounts. Some commerical vendors and international organizations also have quarterly or semi-annual figures on the general government budget of several countries, but, with the exceptions of the countries included in this paper, these are to varying extents interpolated from annual figures.

${ }^{15}$ The sources for both the fiscal and the national income accounts data are: the NIPA accounts from the Bureau of Economic Analysis for the US; the DIW National Account files for Germany; the United Kingdom National Accounts and the Financial Statistics files, from the Office of National Statistics, for the United Kingdom; the CANSIM database of Statistics Canada for Canada; and the Australian Bureau of Statistics database for
} 
of the integrated system of national accounts, thus ensuring consistency with other national income account data. In general, all the government budget and national income account data follow the guidelines of the 1993 System of National Accounts. The two fiscal variables used in the VARs, net taxes and government spending, have been constructed from disaggregated data as follows:

Net taxes $=$ Revenues - Transfers

Revenues $=$ Tax revenues + Non-tax revenues

Tax revenues $=$ Direct taxes on individuals + Direct taxes on corporation + Social security taxes + Production taxes

Non-tax revenues $=$ Current transfers received by the general government + Net capital transfers received by the general government

Transfers: $=$ Social security transfers to households + Other transfers to households + Subsidies to firms + Transfers abroad

Government spending on goods and services $=$ Government consumption + Government gross capital formation

Government gross capital formation $=$ Gross fixed capital formation by the government + Net acquisition of non produced non financial assets + Change in inventories

Some sub-items have been reclassified relative to the 1993 SNA definition in order to make each item more homogeneous in terms of its output and price elasticity. Thus, in the 1993 SNA the item "Direct taxes on individuals" includes mostly income taxes, but also property taxes, taxes on land, and poll taxes, all of which are not elastic to output contemporaneously, and licenses and fees paid by households, which are closer to indirect taxes. ${ }^{16}$ The item "Production taxes" includes mostly indirect taxes like VAT, but also payroll taxes, which are more akin to social security taxes, and land taxes, which also are inelastic to GDP contemporaneously. Whenever possible, I have reclassified all revenue items that are inelastic to GDP into "Current transfers received by the government" or "Net capital transfers received by the government"; ${ }^{17}$ I have also reclassified payroll taxes into "Social security

\footnotetext{
Australia.

${ }^{16}$ Licenses and fees paid by businesses are included in production taxes.

${ }^{17}$ In the 1993 SNA, "Current transfers received by the government" include items such as fees and penalties and transfers from international cooperation; "Net capital transfers received by the government" include mainly taxes on ownership and betterment of land, death and gift duties, and capital transfers to private and public enterprises to cover operating deficits. Thus, both components of non-tax revenues are inelastic to output within the quarter. Note that in some countries, like Germany and Australia, net capital transfers are not reported on a quarterly basis.
} 
taxes", and licenses and fees paid by households into "Production taxes".

The item "Social security tranfers" includes unfunded pension liabilities contributions by the government; as these items also appear as social security contributions, they wash out when constructing net taxes.

The item "Government consumption" (or "Current spending on goods and services") is net of market sales by the government and of capital consumption allowances, an item which is usually imprecisely measured. The item "Government gross capital formation" includes the change in inventories, but often quarterly data on acquisition of non produced non-financial assets (a very minor item) are missing.

The items "Property income received" and "Property income paid" by the government - mostly interest, but also rents and dividends from state owned enterprises - are excluded, for two reasons: there coverage tends to be spotty in quarterly data, and there are economic reasons to focus on the primary budget.

Under the guidelines of the new 1993 National Income Account Systems, all budget items should be recorded on an accrual basis. If this were indeed the case, there would be no issue of collection lags: all taxes would be recorded at the time the corresponding liability arises. In reality, even in the new system taxes are at most recorded on a "modified cash" basis, which consists in adjusting for the lag between the time taxes are withheld by the employer or paid by the taxpayer and the time they are recorded by the agency in charge of collecting them.

The series cover the whole budget of the general government (central government + state and local governments + social security funds), not just a few items. This is important because most theories postulate that the effects of a budget item also depend on the concomitant and expected movements in the others. Covering the whole general government is also important because from the point of view of the private sector an increase in income taxes by the local government is likely to have similar effects, to a first approximation, as the same increase by the central government.

Among the other data, the short interest rate is often the binding constraint on the length of the sample. I use an interest rate as close as possible to a Central Bank instrument, provided an unbroken series is available from the early 1960s. ${ }^{18}$

\footnotetext{
${ }^{18}$ All interest rates are expressed on an annual basis. In the benchmark specifications, I use the Federal Funds Rate in the USA; the interest rate on three month bills for the United Kingdom (variable 11260CZ, International Financial Statistics of the International Monetary Fund); the three month interbank rate in West Germany (series IRS in the OECD Quarterly National Accounts database); the treasury bill rate in Canada (series 15660CZ, International Financial Statistics of the International Monetary Fund); and the
} 


\subsection{Constructing the output and price elasticities}

The coefficients $\alpha_{j k}$ 's in equation (2) are weighted averages of the elasticity of each component of net taxes and government spending. ${ }^{19}$

Consider first the output elasticity of net taxes. The output elasticity of each component of tax revenues is constructed from a decomposition of actual revenues into a tax rate and a tax base. Start with direct taxes on individuals, typically the largest component of tax revenues. This can be written as: ${ }^{20}$

$$
H_{t}=S\left(W_{t} P_{t}\right) W_{t}\left(E_{t}\right) E_{t}\left(Y_{t}\right)
$$

where $H_{t}$ is total real direct taxes on individuals, $S$ is the tax rate, $W_{t}$ is the real wage, $P_{t}$ is the GDP deflator, $E_{t}$ is employment, and $Y_{t}$ is output. Thus, $W_{t} E_{t}$ is the tax base (ignoring non-labor income). Letting lower-case letters denote logs, and totally differentiating, one obtains:

$$
\begin{aligned}
d h_{t} & =\frac{\partial s}{\partial w_{t}} d w_{t}+\frac{\partial w_{t}}{\partial e_{t}} d e_{t}+\frac{\partial e_{t}}{\partial y_{t}} d y_{t}+\frac{\partial s}{\partial p_{t}} d p_{t} \\
& =\left[\left(\frac{\partial s}{\partial w_{t}}+1\right) \frac{\partial w_{t}}{\partial e_{t}}+1\right] \frac{\partial e_{t}}{\partial y_{t}} d y_{t}+\frac{\partial s}{\partial p_{t}} d p_{t}
\end{aligned}
$$

Thus, the term multiplying $d y_{t}$ in $(5 \mathrm{~b})$ is the equivalent of $\alpha_{t y}$ in equation (2a) for this particular tax revenue, and the term $\partial s / \partial p_{t}$ is the equivalent of $\alpha_{t p}$

For most member countries, the OECD computes the elasticity of tax revenues per person to average real earnings, the term $\partial s / \partial w_{t}+1$ in (5b), using information on the tax code of each country and the distribution of tax payers in each bracket, at intervals of a few years. ${ }^{21}$ Following Blanchard and Perotii [2002] I then estimate the contemporaneous elasticity of the real wage to employment, $\partial w_{t} / \partial e_{t}$, as the coefficient on lag 0 from a regression of the log change in real wage on lead 1 and lags 0 to 4 of log employment changes; and I estimate the elasticity of employment to output, $\partial e_{t} / \partial y_{t}$, in a similar way. ${ }^{22}$ A similar methodology can be used to estimate the elasticity of social security taxes to output.

interest rate on three month Treasury notes in Australia (series VNEQ.UN_RTN until decmber 1997 and FIRMMTNIY3 since January 1998, from the Reserve Bank of Australia database).

${ }^{19}$ For West Germany, I do not have a quarterly breakdown of income taxes into individual and corporation income taxes. I use yearly figures to construct the relevant weights.

${ }^{20}$ This formalizes the approach followed by the OECD to construct annual elasticities: see e.g. Giorno et al. [1995].

${ }^{21}$ Data on $\partial s / \partial w_{t}+1$ are obtained from Giorno et al. [1995] until 1992, and from van den Noord [2002] after 1992.

${ }^{22}$ The estimated contemporaneous quarterly employment elasticity of wages is typically 
To estimate the output elasticity of the corporate income tax, I first regress the log difference of the tax base (the operating profits of financial and non financial corporations) on lags -1 to 4 of the log difference of output; the estimated coefficient on lag 0 provides the elasticity of the tax base to output. Because corporate income taxes are usually proportional, the elasticity of corporate income tax revenues to the tax base is assumed to be 1. Finally, the elasticity of production taxes to output is assumed to be 1 .

This is not the end of the story, however, because in several countries some taxes are collected with substantial lags with respect to the transaction that generates the tax liability. For instance, corporation taxes in the UK are due several quarters after the end of the corporation's fiscal year; in Australia and West Germany quarterly installments of the corporation income tax are based on the previous year's assessed tax liability; the same is true for income from self-employment in Australia, Canada, United Kingdom, and West Germany. In these cases, the contemporaneous quarterly elasticity of the tax revenue to its tax base is effectively 0 , even though the statutory and the yearly elasticities are positive (see Appendix 1 for details). When taxes on self employment income have an effective elasticity of zero, I adjust the elasticity of income taxes on individuals by multiplying the value in brackets in $(5 \mathrm{~b})$ by the ratio of self-employment to total employment, or of self-employment income to total wages and salaries. If possible, I also estimate $\partial w / \partial e$ and $\partial e / \partial y$ by using data on dependent employment only instead of total employment. As discussed in section ??, the quarterly output elasticity of all components of non-tax revenues is likely to be about 0 .

Information on the output elasticity of transfers is more limited, but an educated guess suggests it is small. Items like old age, disability and invalidity pensions - the bulk of transfers to households - do not have built-in mechanisms that make them respond automatically to changes in employment or output contemporaneously. Unemployment benefits obviously do, but they typically account for a small part of government spending: in 199495, the largest spender on unemployment compensation was Australia, with 1.64 percent of GDP; if all active and passive measures are included, the largest spender was West Germany, with 3.03 percent of GDP. ${ }^{23}$ In all cases the sum of spending on passive and active measures was less than 10 percent of total government expenditure. Hence, I assume an output elasticity of transfer of -.2. This is rather generous, and allows for spillover effects in

negative in Australia and very small, with a t-statistic below .5, in the United Kingdom. The same is true for the output elasticity of employment in Australia. When the estimate of $\partial w / \partial e$ or of $\partial e / \partial y$ is negative or its t-statistic is below 1 , as a rule I set them to 0 in constructing the elasticities.

${ }^{23}$ See OECD [1996]. Data for West Germany are unvailable. 
other programs: for instance, some anti-poverty programs like AFDC in the US might display some within-quarter elasticity to output. As we will see, however, reasonable alternative values of the output elasticity of transfers make essentially no difference to the results.

Now consider the price elasticity of net taxes, $\alpha_{t p}$. For individual income taxes and social security taxes, the elasticity of real revenues to the price level, holding constant employment, output and the real wage, is equal to $\partial s_{t} / \partial w_{t}$, which can be obtained by subtracting 1 from the OECD estimate of the elasticity of tax revenues per person to average real earnings. It is well known that inflation has many and complex effects on corporate income tax revenues, in both directions. Any attempt to quantify these effects in all of the countries studied in this work would deliver extremely unreliable results. Hence I assume a 0 price elasticity of real corporate income taxes. ${ }^{24}$ I also assume a 0 price elasticity for production taxes and non-tax revenues.

Many transfer programs are indexed to the CPI; however, indexation typically occurs with a substantial lag. A review of indexation clauses in OECD countries in the postwar period did not uncover any government spending program that has been or is indexed to inflation contemporaneously at quarterly frequency. Hence, I set the quarterly price elasticity of real government transfers to -1 .

Turn now to the output and price elasticities of government spending on goods and services, the coefficients $\alpha_{g y}$ and $\alpha_{g p}$ in equation (2b). It is hard to think of any quantitatively relevant mechanism by which government consumption or investment should respond automatically to output contemporaneously: consequently, I set $\alpha_{g y}=0 .{ }^{25}$ The elasticity of real government spending to the price level is more complicated. Consider first the wage component of current spending on goods and services (typically, slightly less than half the total spending). While government wages were indexed to the CPI during part of the sample in some countries, in all cases indexation occurred with a considerable lag, well above one quarter. Hence, real government spending on wages is likely to have an elasticity to the GDP deflator of -1 .

Some of the non-wage component of government spending on goods and services might be fixed in nominal terms within the quarter, implying a price elasticity of real spending equal to -1 . Other parts, like spending on drugs in

\footnotetext{
${ }^{24}$ In a detailed study on the effects of inflation on government revenues and expenditure in Sweden, Persson, Persson and Svensson [1998] conclude that it is impossible to quantify credibly the effects of inflation on corporate income taxes. They also assume a zero inflation elasticity of corporate income taxes.

${ }^{25}$ A typically cited counterexample is disaster relief; however, this spending item is minimal, particularly in the countries included in this study.
} 
nationalized health services, might be effectively indexed to the price level within the quarter, implying an elasticity of 0 . Overall, a price elasticity of real government spending well below 0 seems justified. In my benchmark specifications, I will assume $\alpha_{g p}=-.5$.

Because I only include the primary budget of the general government, I set the interest rate semi-elasticity of both net taxes and government spending to 0: $\alpha_{g i}=\alpha_{t i}=0$. This is probably a safe assumption for government spending; it is slightly more uncertain for net $\operatorname{taxes}^{26}$. Note that, when studying the effects of government spending, the tax elasticity plays no role.

Having constructed the output and price elasticity of each component of net taxes, the elasticity of net taxes is constructed as weighted averages of the elasticities of each components. Table 1 shows the net tax elasticities to output and to the GDP deflator in each country over the whole sample and the main subsamples. ${ }^{27}$ The output elasticity is very low in Australia, mainly for two reasons: the quarterly output elasticity of direct taxes on individuals is zero, because both the estimated output elasticity of real wages to employment and of employment to output are zero; and corporate income taxes have zero contemporaneous elasticity to their tax base, because quarterly installments are paid on the previous year's assessed tax liability. The elasticity is slightly larger in the UK, which has a similar tax system to Australia but a small positive output elasticity of employment; it is still larger in West Germany, with a still higher output elasticity of employment. ${ }^{28}$ It is highest in Canada and USA, the only two countries where corporate income taxes have a positive contemporaneous elasticity to corporate profits (see Appendix 1). It is well known that in quarterly data corporate profits are highly elastic to output (in both Canada and the US, the estimated contemporaneous output elasticity of profits is above 4): this accounts for the large contribution of corporate income taxes to the aggregate elasticity of net taxes in countries with a non-zero contemporaneous elasticity of corporate income tax revenues

\footnotetext{
${ }^{26}$ One could argue that the individual income tax base includes interest income, which would imply a positive interest rate semi-elasticity of individual income taxes. Yet it also includes dividend income, which might covary negatively with the interest rate. Like for the effects of prices, the effects of interest rates on corporate income tax revenues are extremely complex. Canzoneri et al. [2002] conduct a careful exercise to quantify the interest semi-elasticity of net taxes.

${ }^{27}$ Note that in general this elasticity varies over time, because so do the real wage elasticity of tax revenues per person computed by the OECD, the estimated elasticities of real wages to employment and of employment to output, and the estimated output elasticities of corporate profits.

${ }^{28}$ Note that in all these three countries, the estimated employment elasticity of real wages is either negative (Australia, West Germany) or positive but with a t-statistics below 1 (UK), hence it has been set to 0 according to the rule described above.
} 
to corporate profits.

\section{A first look at the estimates}

\subsection{Do the fiscal shocks make sense?}

Are the estimated fiscal shocks reasonable? This is a rather loose question, but a legitimate one (see Rudebusch [1998]). Since the key facts of US fiscal policy are much better known, I will limit the analysis to the US case. Figure 1 displays the estimated government spending and net tax shocks, $e_{t}^{g}$ and $e_{t}^{t}$, from the benchmark 5 variable VAR on the whole sample, multiplied by the average share of government spending and net taxes in GDP, respectively, to express them as shares of GDP. The shaded areas correspond to the three years following and including the onset of the two Ramey and Shapiro episodes in this sample, the Vietnam war buildup that started in 1965:1 and the Carter- Reagan buildup that started in 1980:1.

The estimated shocks capture well the first buildup, much less so the second one. There are several reasons for this: total government spending on goods and services rose at a much faster rate in 1966 and 1967 (10 percent and 7 percent, respectively) than in 1980,1981 and 1982 (2, -.1, and 1 percent, respectively). It is not often appreciated that, while defense spending rose at an average rate of about $6 \%$ between 1980 and 1981, non defense current spending on goods and services did not move in real terms, and nondefense capital spending fell at an average rate of about 4 percent. Note that the estimated fiscal shock captures much better the increase in government spending on goods and services between 1984 and 1987, when the latter rose at an average rate above 4 percent, with non-defense current and capital government spending rising at average rates of 3 and 6 percent, respectively.

The structural net tax shock captures well the 1968 tax surcharge and the (much larger) 1975. It is mostly positive between 1980 and 1982; this however is easily explained in view of the large fall in GDP per capita in 1980 (-1.3 percent) and especially in 1982 (-3 percent).

\subsection{Subsample stability}

Table 2 displays the results from a standard Chow test on each reduced form regression, with a break point in 1980:1 (1975:1 in West Germany). There is substantial evidence of instability: in each country except West Germany at least two of the five Chow tests have a p-value smaller than .05. We will see that the impulse responses to fiscal shocks have very different properties 
in the two subsamples. ${ }^{29}$

\section{The effects of government spending on out- put}

\subsection{Effects on aggregate GDP}

Table 3 and Figure 2 display the effects of a shock to $e_{t}^{g}$ equal to 1 percentage point of $\mathrm{GDP}^{30}$, from a VAR in 5 variables with $g$ and $t$ ordered first and second, respectively; the benchmark case displayed in this table also assumes an elasticity of real government spending to prices equal to -.5. To allow a comparison of the results across the 5 countries in a compact way, the table displays the responses of GDP on impact and after 4, 12 and 20 quarters, and the maximum and minimum GDP response up to 20 quarters, with the quarter at which it occurs (the maximum GDP response will also be called the "government spending multiplier" in what follows). The two lines on each side of the impulse response give one standard error bands, computed by Monte Carlo simulations based on 500 replications, as in e.g. Stock and Watson [2001].

Over the whole sample, the impact response is positive and significant in all countries. For the US, this is consistent with the positive response estimated by Blanchard and Perotti [2002], Edelberg, Eichenbaum and Fisher [1999], Fatas and Mihov [2001], Canzoneri, Cumby and Diba [2002], and Mountford and Uhlig [2002]. The size of the impact response is similar in all countries, between .3 and .4 percentage points (pps) of GDP except in West

\footnotetext{
${ }^{29}$ Even if the break were in a part of the structural VAR different from the fiscal policy equations, it would appear in the whole reduced form and hence it would confound the identification of the fiscal shocks and the impulse responses to fiscal shocks.

The Chow test assumes that we know the time of the possible structural break, which we do not. There is mounting evidence in some recent literature of a breakdown in several macroeconomic relations around 1980 (see e.g. Stock and Watson [2002]). A downside of this procedure is that the break date chosen here is not strictly speaking exogenous, implying that the critical values of the conventional Chow test used here are too small.

A common alternative would have been to use a test, like the Andrews [1993] sup-Wald test, that does not assume such knowledge. But because of the very large number of parameters in the reduced form, the small sample properties of the latter test might be problematic.

${ }^{30}$ The impulse response of government spending and taxes are multiplied by their respective average shares in GDP to obtain impulse responses in terms of shares of GDP. The actual response of government spending on impact is usually slightly different from 1 , because of the feedback from ouput and price changes to $g_{t}$ (recall that the shock is on $\left.e_{t}^{g}\right)$
} 
Germany, where it is 1.30 pps of GDP. In fact, over the first 3 years, in all countries the largest effect on GDP occurs on impact; in the US, after about 4 years GDP has the absolute peak at about 1 pp of GDP. Thus, in no case is the maximum GDP response much larger than 1, and in three countries it is less than $.5 .^{31}$

These results, however, hide a substantial difference between the first and second halves of the sample. When the model is estimated over the two subsamples separately ${ }^{32}$, the pattern that emerges is rather clear: in all countries except Australia, the effects of government spending shocks on GDP in the post-1980 period are substantially smaller than in the pre-1980 period. In fact, in the post-1980 sample the response of GDP in the first four countries is never significantly positive (except for West Germany on impact), and it becomes significantly negative within the first 3 years. The minimum response in all these countries is always smaller than -1 , and significant.

One may wonder whether these results are due to a fundamental difference in the government spending process over the two subsamples, in particular if the government spending response to its own shock is less persistent in the post-1980 period. Table 4 shows clearly that this is not the case. The cumulative response of government spending (as a share of GDP) to a government spending shock at quarters 4,12 and 20 (columns 1 to 3 ) is remarkably similar across countries: for instance, at quarter 4 in the whole sample it ranges from $2.89 \mathrm{pp}$ of GDP in Australia to 3.55 in the US. It is also similar across subperiods, with the exceptions of West Germany and the UK after 3 or more years.

The cumulative multipliers ${ }^{33}$ (columns 4 to 6 of Table 4 ) provide an even clearer picture: except for Australia, they are uniformly much higher in the pre-1980 period than in the post-1980 period. In the latter, the cumulative output multiplier is 0 after 4 quarters, and substantially negative after 12 quarters (except in the US where it is essentially 0). As before, these inequalities are reversed in Australia.

Note that the largest multiplier at 4 quarters is observed in West Ger-

\footnotetext{
${ }^{31}$ The shape of the impulse response is qualitatively similar in all countries (see Figure 2): after the initial rise, GDP starts declining, and after about 4 quarters it rises again; only in Germany and the US, however, is this second increase economically and statistically significant.

${ }^{32}$ When estimating the model over different subsamples, each time I recompute the average elasticities over the relevant subsample. In doing so, if data are available I also reestimate the output elasticity of employment and the employment elasticity of wages over the relevant subsamples.

${ }^{33}$ The cumulative multiplier at quarter $\mathrm{x}$ is defined as the ratio of the cumulative response of GDP at quarter $\mathrm{x}$ to the cumulative response of government spending at the same quarter.
} 
many, at 12 quarters in the US, and at 20 quarters in the US and Canada. Hence, while the results are mildly supportive of the notion that the most closed economy of the group tends to have larger multipliers, the ranking is not as clear cut as a standard leakage argument would suggest.

It is interesting to compare the estimated cumulative multipliers from this exercise with the cumulative multipliers typically provided by large scale econometric models. This is done in Table $5 .^{34}$ The large scale macroeconometric models tend to predict larger cumulative multipliers than those estimated here, in particular those estimated on the post-1980 sample.

\subsection{The role of monetary policy}

One could argue that differences in the government spending multipliers, both over time and across countries, might be caused by differences in the behavior of the monetary authorities.

Table 6 displays the effects of a unit shock to governments spending on the nominal (first 4 columns) and real (columns 5 to 8 ) short interest rates, as well as on the cumulative deficit (last 4 columns). ${ }^{35}$ Consider the nominal interest rate first. In the US, it falls on impact in all three samples; even after 4 quarters, it declines by -.5 pps in the pre-1980 sample and by 1.4 pps in the post-1980 sample.

This response is puzzling, and indeed it has puzzled other researchers that have also found it in US data, like Mountford and Uhlig [2002] and Edelberg, Eichenbaum and Fisher [1999]; ${ }^{36}$ yet, once again, it is not necessarily typical. Outside the US, in the whole sample the nominal interest rate increases in all countries, except in West Germany after 12 quarters. In the post-1980 period, the nominal interest rate falls also in the UK; in West Germany, Canada and Australia it increases, although in the former it is rather imprecisely estimated.

The real short term interest rate follows a similar pattern. ${ }^{37}$ Over the

\footnotetext{
${ }^{34}$ The multipliers of the macro econometric models are from Sims [1988], who in turn summarizes the results of the Brookings comparison project (see Bryant et al. [1988]). It should be noted that some models have changed since then, in particular more models have incorporated forward - looking behavior.

Also, it is well known that it is very difficult to compare the output of simulations across models, because it is very difficult to hold "everything else" constant. The use of cumulative multipliers is intended to minimize this problem.

${ }^{35}$ Strictly speaking, this exercise is fully meaningful only under flexible exchange rates.

${ }^{36}$ Canzoneri, Cumby and Diba [2002] find a prolonged, though small, increase in the federal funds rate after a spending shock.

${ }^{37}$ The real interest rate is defined here as $i_{t}-\left(E p_{t+4}-p_{t}\right)$. If the alternative definition $i_{t}-4\left(E p_{t+1}-p_{t}\right)$ had been used, in some cases the real interest rate would have displayed
} 
whole sample, after 4 quarters it falls in the US and, very marginally, in Australia; it increases in the other countries. In all cases, the response is rather precisely estimated. In the post-1980 period, it falls the US and in the UK, and it increases in the other three countries.

Can the difference in the output response between the pre- and post-1980 samples be explained by a stronger interest rate response in the latter? No. ${ }^{38}$ Only in Canada does the real interest rate at 4 quarters increase more in the post-1980 sample than in the pre-1980 sample; in all other countries, it increases less, or falls more.

Can the difference in the output response across countries be explained by a different behavior of the real interest rate? The answer is unclear. In the post-1980 sample, the real interest rate falls after 4 quarters in the UK, but the cumulative multiplier at the same horizon is also negative. If one excludes the UK, the two countries with the largest real interest rate response at 4 quarters in the post-1980 sample, West Germany and Canada, also have the lowest cumulative multiplier.

What about the reverse direction of causality, i.e. can the behavior of the real interest rate be explained by the cumulative deficit? Not really. The last 4 columns of Table 6 display the cumulative deficit response to the government spending shock. Consider the post-1980 sample for brevity. The country with the largest increase in the cumulative deficit after 4 quarters, the UK, also has the second largest fall in the real interest rate; conversely, the country with the second smallest increase in the deficit, West Germany, also has the second largest increase in the real interest rate at the same horizon.

\subsection{Other robustness checks}

All the impulse responses presented so far were recomputed under the assumption that government spending is ordered second, after net taxes. The differences were minimal: typically the point estimates of the impulse responses at all horizons change by only a few undredthos of a percentage point.

a very large fall in the first few quarters (in the order of 3 or 4 pps), due to the large and irregular behavior of the price response in the very first quarter.

The post-1980 sample in the US includes two possibly very different monetary regimes: the Volcker experiment and the subsequent Volcker-Greenspan regime. The results are robust to the omission of the Volcker experiment, 1979:4 to 1982:3.

${ }^{38}$ One important caveat: the short-term real interest rate might not be the most appropriate interest rate variable for this exercise. In particular, to study the response of GDP and its components the long term interest rate might be more appropriate. The study of the role of the long term interest rate is left for future research. 
The results are also robust to the exclusion of some years between 1973 and $1976^{39}$, and to the exclusion of other specific years, motivated by standard periodizations in monetary policy (for instance, the 1979:4 - 1982:3 Volcker experiment in the post -1980 period in the US, or the 1990:4 - 1992:3 hard-ERM period in the United Kingdom).

Finally, I routinely estimate all impulse responses over the post - Bretton Woods flexible exchange rate period. In the interest of space, I do not present these estimates; in general, they appear to be intermediate between the responses of the two subsamples.

\section{Effects on GDP components}

Table 7 displays the effects of government spending on GDP components. The responses are derived from a 6 variable VAR, where each component of GDP is added in turn to the benchmark.

The behavior of private consumption largely mimics that of GDP: it typically increases on impact, and more so in the pre-1980 sample, although only in Australia and the United Kingdom is the difference between the impulse responses in the two samples substantial. In the pre-1980 sample, the maximum effect is larger than 1 in only one country, the US; in the post-1980 sample, it is never larger than .6. By quarter 12, in the post-1980 quarter the response is either insignificantly different from 0 , or significantly negative.

Perhaps more informative is the cumulative consumption multiplier (the cumulative change in consumption divided by the cumulative change in output). In the post-1980 sample, by quarter 4 it is no greater than .2 , except in the US where it is .55; by quarter 12 it has fallen further or it has remained essentially at its quarter 4 level. ${ }^{40}$

Note that once again the US appears to be an outlier; over the whole sample its maximum consumption response is double that of the next highest maximum, and its cumulative consumption response is also by far the highest at all horizons (except for West Germany at 12 quarters).

The private investment responses are typically more irregular, hence summarizing their shapes is more difficult. However, in general the response of investment is smaller than the response of consumption; and once again the

\footnotetext{
${ }^{39}$ The exact periods I exclude are 1974:1 - 1976:4 in the US, and 1973:1 - 1975:4 in Australia, Canada, UK and West Germany. These years are chosen on teh basis of the size of the log change in the price level, real output, real net taxes, and real government spending.

${ }^{40}$ Note that the consumption response is much weaker in the post-1980 period also in Australia, where the GDP response displayed the opposite pattern.
} 
responses at all horizons, the maxima and minima, and the cumulative multipliers, tend to be algebraically smaller in the post-1980 period, with very few exceptions (mostly in Australia).

In the pre-1980 sample the investment response after 12 quarters is positive in the USA and about 0 in all other countries; in the post-1980 sample, at the same horizon it is significantly negative in all countries (except Australia), and remarkably similar - between -.7 and -.1 pp of GDP. In the first sample, the minima are significantly negative in four countries, between .4 and -.8 pps of GDP; in the second sample, the minima are significantly negative in all countries, and large - between -.4 and -2.3 of GDP.

The cumulative multipliers paint a similar picture. They are much smaller in the second sample (with the exception of Australia at quarters 12 and 20), and negative after 12 quarters. ${ }^{41}$

It is difficult to detect a regular pattern in the response of exports and imports. In general, the responses are surprisingly large, and there is some evidence of a systematic positive response of imports. The US is once again an exception to both statements.

\section{How important is monetary policy for fiscal policy? The Sims conjecture}

There are two reasons why it might be important to include interest rate and prices in a VAR with fiscal policy. In the Brookings comparison project of Bryant [1988], typically small scale econometric models displayed larger fiscal multipliers than large scale, rational expectation models that included interest rate and prices (see Table 4). Sims [1988] conjectured that these results could be explained by the presence of financial variables, like interest rates and prices, in the larger scale models; these jump variables embody expectations of future changes in fiscal policy, and absorb some of the estimated effects of fiscal shocks. To test the Sims conjecture, I have estimated a three variable VAR which excludes the interest rate and the GDP deflator.

In order not to clutter the exposition, I do not report the results, but the pattern that emerges is clear. Both the impact effects and the maximum effects of government spending on GDP are smaller in the smaller VAR, albeit usually by very small margins, in both the whole sample and the pre-1980 sample. In the post-1980 sample, the same effects tend to be slightly larger in

\footnotetext{
${ }^{41}$ Notice also the effects of subsample instability: taking for instance the cumulative multipliers at 12 quarters, in three countries out of five the multipliers in the two subsamples are on the same side of the whole sample multiplier.
} 
the smaller VAR, although again by very small amounts, with the exception of the UK.

A second rationale for including the interest rate is that in its absence fiscal shocks might pick up the effects of interest rate shocks if there is some systematic contemporaneous relationship between monetary and fiscal policy. ${ }^{42}$ The same results mentioned above speak against this interpretation.

Another way to address this issue is to reverse the ordering of the (cyclically adjusted) fiscal policy variables and the interest rate (see also Mountford and Uhlig [2002] for a similar exercise). In all specifications so far, cyclically adjusted taxes and government spending could not respond contemporaneously to the interest rate. Suppose instead we assumed the opposite ordering. This is conceptually inconsistent with the assumption that, because of decision lags, fiscal policymakers cannot make discretionary changes to fiscal policy in response to contemporaneous innovations in the other variables. However, this ordering attributes as much as possible of the variation in government spending innovations to interest rate innovations. If the systematic response of monetary policy to fiscal policy is important, one would expect the results to differ substantially now that fiscal shocks are forced to be orthogonal to interest rate innovations. However, the results on the GDP multiplier (not reported to conserve space) are very similar. In this sense, controlling for monetary policy is not important when estimating the effects of fiscal policy on output - a result noted already by Mountford and Uhlig [2002] for the US.

\section{The effects of government spending on prices}

Just as the output elasticity of taxes is a crucial parameter in estimating the effects of taxes on GDP, so is the price elasticity of government spending crucial in estimating the effects of government spending on prices. ${ }^{43}$ To see what is involved, consider a simplified version of the model

$$
\begin{gathered}
u^{p}=\gamma u^{g}+e^{p} \\
u^{g}=\alpha u^{p}+e^{g}
\end{gathered}
$$

where all inessential variables and superscipts have been omitted. $\gamma$ is the effect of government spending on prices; $\alpha$ is the elasticity of real government spending to the price level; $u^{t}$ and $u^{g}$ are the reduced form innovations in

\footnotetext{
${ }^{42}$ Strictly speaking, this argument is relevant in a flexible exchange rate regime only.

${ }^{43}$ See Blanchard and Watson [1986] for an early application of the methodology used here.
} 
net taxes and government spending, and $e^{t}$ and $e^{p}$ are the corresponding structural shocks; as usual, $\operatorname{corr}\left(e^{g}, e^{p}\right)=0$ by assumption. If not all of government spending is indexed, $\alpha<0$. Suppose the researcher assumes an elasticity $\widehat{\alpha}$ different from $\alpha$. Hence, the researcher will estimate $\widehat{e}^{g}=e^{p}+(\alpha$ - $\widehat{\alpha}) u^{p}$, and

$$
\operatorname{cov}\left(\widehat{e}^{g}, u^{p}\right)=\operatorname{cov}\left(e^{g}, u^{p}\right)+(\alpha-\widehat{\alpha}) \operatorname{var}\left(u^{p}\right)
$$

and solving for $\operatorname{var}\left(u^{p}\right)$ and $\operatorname{cov}\left(e^{g}, u^{p}\right)$

$$
\operatorname{cov}\left(\widehat{e}^{g}, u^{p}\right)=\frac{\gamma}{1-\alpha \gamma}\left[1+\frac{(\alpha-\widehat{\alpha}) \gamma}{1-\alpha \gamma}\right] \operatorname{var}\left(e^{g}\right)+\frac{(\alpha-\widehat{\alpha})}{(1-\alpha \gamma)^{2}} \operatorname{var}\left(e^{p}\right)
$$

Thus, if $\gamma>0$ (government spending has a positive effect on prices) but the researcher underestimates (in absolute value) the price elasticity of government spending, typically the estimated effect of government spending on prices will be smaller than the true one. Note also that this bias increases with the variance of the price disturbance.

Indeed, previous VAR investigations on the effects of fiscal policy in the US, like Fatas and Mihov [2001] and Mounford and Uhlig [2002], have often found a negative effect of government spending on prices or inflation. ${ }^{44}$ These results are based on orthogonalizations with real governments spending ordered before prices, thus implicitly assuming a zero elasticity of real government spending to the price level.

Table 8 displays the results of a shock to government spending on the price level under two alternative values for the price elasticity of the former: 0 (first three lines of each country) and -.5 (last three lines), from the same specification used for Table 3. Table 8 makes three important points.

First, the price elasticity of government spending does matter in the short run: with few exceptions (and quantitatively minimal), the response at all horizons and in all samples is larger when the elasticity is -.5 than when it is 0 . In a few countries, increasing the elasticity from 0 to -.5 changes the qualitative conclusions from this exercise quite dramatically: in Australia in particular, the impact effect of a shock to government spending in the pre-1980 sample changes from an implausible -1.6 percent to - .34 percent. ${ }^{45}$

\footnotetext{
${ }^{44}$ Canzoneri, Cumby and Diba [2002] also find a negative impact effect, followed by a gradual increase. Edelberg, Eichenbaum and Fisher [1999] find a negative effect after an initial positive effect.

${ }^{45}$ For the reasons discussed above, even -.5 might be an underestimate of the true price elasticity of government spending. Indeed, if we assumed a price elasticity of government spending of -1 , all the negative impact effects would become positive (results not reported).

Notice that these results are not a figment of the fact that the GDP deflator appears at the denominator of real government spending. When government spending is deflated by its own deflator rather than the GDP deflator, the results are qualitatively similar.
} 
However, the price elastcity of government spending makes little difference at quarter 12 .

Second, for the response of the GDP deflator, even more than for the GDP response, there is evidence of considerable subsample instability. Because the effect on output is much more muted, one might expect to see a smaller effect on the GDP deflator in the post- 80 period. This is usually the case, except in the UK: ${ }^{46}$ even with an elasticity of -.5 , no country exhibits a significantly positive price response at quarter 4 during this period. After 12 quarters, only two countries exhibit a significantly positive response, the UK (1.13pps) and Australia (.8 pps); in all the others, it is essentially 0 .

Third, the US is, once again, an exception. It is the only country where the response of the GDP deflator is negative after 4 and 12 quarters; notice, however, that the large negative response over the whole sample estimated here and in other works becomes much smaller in the two separate subsamples. ${ }^{47}$

The effects of a shock to government spending on the CPI deflator, instead of the GDP deflator, are displayed in Table 9. The pattern that emerges is very similar; except in Canada, in the post-1980 the CPI response appears a bit stronger than the GDP deflator response, but the difference is substantial only in West Germany.

The responses from a similar exercise, but based on a 6 variable VAR which also includes a commodity price index, are also similar. ${ }^{48}$

\section{The effects of taxation}

\subsection{Effects on output}

Table 10 and Figure 3 display the effects of a shock to cyclically adjusted net taxes equal to 1 percentage point of GDP. For each country, the table displays the impulse responses under the benchmark output elasticity of net taxes

\footnotetext{
${ }^{46}$ Also, strictly speaking one would expect the opposite result in Australia, where GDP increases more in the post-1980 sample.

${ }^{47}$ In fact, in all countries the response of the GDP deflator over the two subsamples is considerably smaller, in absolute terms, than the response over the whole sample. In the $\mathrm{UK}$, the response of the GDP deflator is explosive over the whole sample, while it appears stable over the two subsamples.

${ }^{48}$ Following much of the literature, the commodity price index is ordered first. Results when it is ordered last (see Sims and Zha [1998]) are very similar. It should be noted that the reasons for controlling for a commodity price index when estimating the effects of fiscal policy on prices are much less compelling than when estimating the effects of a monetary policy shock.
} 
(first three lines for each country), and under the same elasticity augmented by one (next three lines).

Consider first the results under the benchmark elasticity. The table makes three points. First, the two countries with the largest output elasticity of net taxes (see the last column), the US and Canada, are also the only two countries where the impact effect of taxation on output is consistently negative in all samples, although not larger than -.25 pps. In the other countries, the estimated impact effect is always positive, and significant.

Second, there is again evidence of stronger negative effects of taxation on GDP in the pre-1980 period than in the post-1980 one. For instance, after 4 quarters the response of GDP is negative in all countries in the pre1980 period (although insignificant in Australia); in the post-1980 period it is significantly negative in only two countries, Canada and the UK. More generally, at the same horizon the output response is algebraically larger in the second subsample in four countries out of five.

Third, the tax multipliers (defined as the minimum output response) are not large: in the pre-1980 perios it is usually negative, but larger than one in absolute value only in the US and in West Germany; in the post-1980 period, it is between -.6 and -.7 in Canada and West Germany, close to 0 in the other countries.

The positive estimated output responses in Australia, UK and West Germany are suspicious. These are the three countries with the smaller output elasticities of net taxes (in particular, in the first two the benchmark elasticity is close to 0). As discussed, there are two reasons for this: the very small (or zero, in the case of Australia and the UK) estimated output elasticity of employment and employment elasticity of wages; and the zero elasticity of corporate income taxes to its base, due to the fact that corporations can pay quarterly installments on the basis of the previous year's assessed tax liability. This has a large effect on the estimated output elasticity of net taxes, given the large weight of the corporate income tax in the net tax elasticity.

Both conditions are implausible. In particular, it is likely that corporations would choose to pay quarterly installments based on expected profits, if these differ greatly from the previous year's profits. For each country, the second set of rows in Table 10 displays the impulse response of output under an assumed output elasticity of net taxes equal to the benchmark value, augmented by 1 . As expected, the response of output falls algebraically at virtually all horizons. But in Australia and in the United Kingdom it often remains positive, or negative but stubbornly small. Reassuringly, note that the size of the tax multiplier seems to be largely independent of the net tax elasticity.

Thus, the evidence suggests that the effects of taxation on output are not 
large; once again, the effects estimated previously for the US (see e.g. Blanchard and Perotti [2002]) seem to be towards the high end of the spectrum.

It is interesting to relate the ranking of the tax multipliers with that of the government spending multipliers. In the pre-1980 period, the US and West Germany have by far the two highest tax and spending multipliers; Canada and the UK have intermediate spending multipliers, and intermediate tax multipliers; finally, Australia has the smallest spending and tax multipliers. In the post-1980 period, as we have seen in most countries the response of output to a government spending shock is mostly negative; there is indeed a very close match between the rankings of the minimum responses to a spending shock and to a net tax shock.

One might wonder how government spending responds to tax shocks, and whether this could explain some of the variation in the output response, over time and across countries. This is unlikely. Government spending never increases more than .2 pps of GDP at any horizon and in either subsample. The exception is West Germany, where it increases by .6 pps on impact and by .4 pps after 4 quarters; this might help explain the positive GDP response on impact (although note that GDP turns significantly negative after 4 quarters).

Table 11 reports the cumulative effects of a net tax shock on net taxes (first three columns) and the cumulative tax multiplier (last three columns). In general, the response of net taxes to their own shock is mush less persistent than the response of government spending to its own shock; there is also some more dispersion over time and across countries. Note however the very similar cumulative response of net taxes at 4 quarters in the post-1980 period. ${ }^{49}$

\subsection{Effects on interest rates}

Table 12 displays the effects of net tax shocks on nominal and real interest rates, and on the cumulative deficit. In the whole sample, net tax shocks have positive impact effects on the nominal interest rate in three countries (USA, Canada, and Australia), all around .2 pps, and essentially no impact effect in West Germany and the UK. But in the latter two countries, the nominal interest rate increases significantly after 4 quarters, while in Canada and the US it goes back to essentiaslly 0 . After 3 or more years, the interest rate response is 0 or negative in all countries except Australia. Thus, broadly

\footnotetext{
${ }^{49}$ Note that in some cases the cumulated effect on net taxes is close to zero, generating very large net tax multipliers. In general, the cumulative tax multiplier is not as interesting as the cumulative government spending multiplier because of the strong endogeneity of tax revenues.
} 
speaking the nominal interest rate response is positive in the short run, and negative or zero in the longer run

With the exception of West Germany after 4 quarters, the nominal interest rate response in the pre-1980 period is usually algebraically smaller than in the post-1980 period. This is consistent with the larger negative effects of net taxes on demand in the first period.

The impact increase in the nominal interest rate in response to a tax shock can be explained in two ways. ${ }^{50}$ First, joint tightening by fiscal and monetary authorities; ${ }^{51}$ second, reverse causation: when interest income increases, tax revenues from non-labor income also increase.

Note that, with the partial exception of West Germany (where as we have seen government spending increases more), in response to a tax shock the cumulative deficit falls by very similar amounts in all countries at quarters 1 and 4, and even at quarter 12 (except that in West Germany the deficit actually increases).

\subsection{Effects on prices}

Table 13 displays the effects of a tax shock on prices. For each country the first three lines display the results under the benchmark price elasticity; the next three lines under the same elasticity, less .5. In the full sample, the impact effect on prices is negative in three countries (UK, Canada, Australia), and 0 in the others. After 4 quarters it is still significantly negative in Australia and Canada, and positive only in West Germany.

There is evidence of a stronger negative effect of net taxes on prices in the pre-1980 period, except in the US. This is consistent with the stronger negative effects on GDP and demand during the same period. In the post1980 period, the effects of tax shocks on prices are negative but small in the short run; after 3 years, there is some evidence of a positive effect in two countries, although only in Australia is this positive effect large.

Is there a relation between the effects of government spending on prices and those of net taxes? At quarter 4, we have seen that usually the effects of government spending are insignificant; but at quarter 12, government spending shocks and net tax shocks all have effects on prices of the same signs,

\footnotetext{
${ }^{50}$ As noted by Canzoneri, Diba and Cumby [2002], the increase of the interest rate in response to a net tax shock in the US and Canada appears inconsistent with a Taylor rule, since both output and prices also fall.

${ }^{51}$ This explanation might be consistent with the fall in the nominal interest rate in response to a positive government spending shock that occurs in two countries in the post-1980 period. However, only in the US does the interest reate increase in response both to a negative government spending shock and to a positive net tax shock.
} 
although not always significant.

\section{Conclusions}

What can account for the decline in the efficacy of fiscal policy? First, all the economies in the sample have become more open over time, but the increase in the export / GDP ratio is probably too small to account for the large changes in the government spending multipliers. Second, for more than half of the first period the countries of the sample were on a fixed exchange rate regime: a standard Mundell - Fleming model would predict that fiscal policy is less powerful under flexible exchange rates. However, there is no evidence of a systematic crowding out of exports in the second sample. Third, the behavior of the monetary authorities might have changed in the second part of the sample. Yet, in response to a fiscal shock the real interest rate increases less or falls more in the second period than in the first, except in Canada. Fourth, credit markets have probably become more developed in the second period, and as a consequence the share of credit constrained consumers might have fallen. Theoretically, the fiscal multiplier can be larger if individuals are liquidity constrained (see e.g. Perotti [1999]). The macroeconomic importance of the relaxation of credit constraints is however far from being well understood. Fifth, financial markets might have reacted more strongly in the second period, an interesting possibility that still awaits an empirical exploration.

All these results are of course conditional on the specific methodology used to identify the fiscal shocks. It is therefore important to be aware of its potential shortcomings. The VARs used to estimate the fiscal shocks have low dimensionality; to the extent that there are some important omitted variables, the true one-quarter-ahead forecats error (in, say, the CBO estimates in the case of the US), could be much smaller than the forecats error estimated here, and the fiscal shocks could be misestimated. Fatas and Mihov [2001] and Canzoneri, Cumby and Diba [2002] study the response of macroeconomic and financial variables to forecast revisions of the deficit by the CBO. As a related point, and as discussed in section 2.2, implementation lags could undermine the unpredictability of the estimated fiscal shocks. This is undoubtedly a danger in the methodology used in this paper. Blanchard and Perotti [2002] show how to address this issue, under the maintained assumption that fiscal policymakers cannot respond to output shocks for at least two quarters, instead of one as assumed so far. They show that for the US taking into account anticipated fiscal policy does not change the results substantially. A similar exercise here would carry us far afield. However, it 
is important to note that anticipated fiscal policy is unlikely to undermine what is perhaps the most interesting result of this paper - the decline in the potency of fiscal policy over the last twenty years. While anticipated fiscal policy might well bias the estimated impulse response downward, it is difficult to see why it should do so more in the second part of the sample. 


\section{Appendix 1: Tax elasticities and col- lection lags}

This Appendix reports the contemporaneous tax elasticities, collection lags, and quarter dependence for cash tax revenues. For true accrual measures of tax revenues, the tax elasticity would always be the statutory tax elasticity, as measured by the OECD, and the notion of collection lags would not apply.

\section{United States}

Individual income tax. (i) Income from employment: withholding system. Contemporaneous elasticity to real earnings per person: OECD elasticity. Collection lags: none. (ii) Income from self-employment and business: quarterly installments of income tax based on expected income. Contemporaneous elasticity to real earnings per person: OECD elasticity. Collection lags: none.

Corporate income tax. Each corporation can have its own fiscal year different from the tax year. Large corporations are required to make quarterly installment payments, of at least .8 of the tax final tax liability. No penalty was applied if the estimated tax liability is based on previous year's tax liability; this exception has been gradually phased out from 1980 on. Contemporaneous elasticity to tax base: 1 , although it could be lower at the beginning of the sample until the mid eighties, when a company could base its estimated tax liability on the previous year's tax liability. Collection lags: none.

\section{United Kingdom}

Individual income tax. (i) Income from employment and pensions: weekly withholding during entire sample. Contemporaneous elasticity to real earnings per person: OECD elasticity. Collection lags: none. (ii) Income from self-employment: same tax rates as for income from employment (with proportional surcharge). For tax year ending April 1 of year t, two lump sum payments on January 1 and July 1 of year t, based on assessment for fiscal year ending April t-1. Contemporaneous elasticity: 0.

Corporate income tax: For companies started before 1965: If the company's accounting period ends before March 31st of year t, the tax is due January 1 of year $t+1$. If the company's accounting period ends after March 31st of year $t$, the tax is due January 1 st of year $t+2$. Hence, the lag in the payment is between 9 and 21 months. For companies started after 1965: the tax is due 9 months after the end of the accounting period. Contemporaneous elasticity: to tax base: 0 .

\section{Canada.}


Individual income tax. (i) Income from employment: withholding system. Contemporaneous elasticity to real earnings per person: OECD elasticity. Collection lags: none. Quarter dependence: none. (ii) Income from selfemployment and business: If an individual has less than $25 \%$ of his income from dependent employment, required to pay quarterly installments of income tax on expected income. Expected income is mostly based on previous year's income. Contemporaneous elasticity: 0. .

Corporate income tax. Each corporation has its own fiscal year. The taxation year is jan 1 to Dec 31 , and covers corporations whose fiscal year ends within this calendar year. Corporations must pay quarterly installments on expected income. Contemporaneous elasticity to tax base: 1 .

\section{West Germany}

Individual income tax. (i) Income from employment: withholding system. Contemporaneous elasticity to real earnings per person: OECD elasticity. Collection lags: none. (ii) Income from self-employment and business: quarterly installments of income tax based on previous year's assessed tax liability. Contemporaneous elasticity: 0.

Corporate income tax. Quarterly installments, based on previous year's assessment Contemporaneous elasticity to tax base: 0 .

\section{Australia}

Individual income tax. (i) Income from employment: withholding system. Contemporaneous elasticity to real earnings per person: OECD elasticity. Collection lags: none. (ii) Income from self-employment and business: installments of income tax based on previous year's assessed tax liability. Contemporaneous elasticity: 0 .

Corporate income tax. Quarterly installments, based on previous year's assessment. Contemporaneous elasticity to tax base: 0 . 


\section{References}

Alesina, Alberto, Silvia Ardagna, Roberto Perotti, and Fabio Schiantarelli [2002]: "Fiscal Policy, Profits, and Investment", forthcoming, American Economic Review

Andrews, Donald W.K. [1993]: "Tests of Parameter Instability and Structural Change with Unknown Change Point", Econometrica, 61, 821-56

Bagliano, Fabio and Carlo A. Favero [1997]: "Measuring Monetary Policy with VAR Models: An Evaluation", Centre for Economic Policy Research, Discussion Paper: 1743, November 1997

Bernanke, Ben S. and Alan S. Blinder [1992]: "The Federal Funds Rate and the Channels of Monetary Transmission", American Economic Review, 82(4), September, 901-21

Bernanke, Ben S. and Ilian Mihov [1998]: "Measuring Monetary Policy", Quarterly Journal of Economics; 113(3), August, 869902

Blanchard, Olivier and Roberto Perotti [2002]: "An Empirical Characterization of the Dynamic Effects of Changes in Government Spending and Taxes on Output", forthcoming, Quarterly Journal of Economics

Blanchard, Olivier J and Mark W Watson [1986]: "Are Business Cycles All Alike?", in : Gordon, Robert J., ed.: The American business cycle: Continuity and Change, National Bureau of Economic Research Studies in Business Cycles series, vol. 25, Chicago and London: University of Chicago Press, 12356

Boivin, Jean and Marc Giannoni [2002]: "Has Monetary Policy Become Less Powerful?", mimeo, Columbia University

Bryant, Ralph. C., Dale. W Henderson, Gerald Holtman, Peter Hooper, and Steven A. Symansky, eds. [1988]: Empirical Macroeconomics for Independent Economies, The Brookings Institutions, Washington, D.C.

Burnside, Craig, Martin Eichenbaum, and Jonas D.M. Fisher [2001]: " Assessing the Effects of Fiscal Shocks", mimeo, Northwestern University

Canzoneri, Matthew B., Robert E. Cumby and Behzad T. Diba [2002]: "Should the European Central Bank and the Federal Reserve Be Concerned About Fiscal Policy", paper presented at the Federal Reserve Bank of Kansas 
City's symposium on "Rethinking Stabilization Policy", Jackson Hole, August 29-31 2002

Christiano, Lawrence J, Martin Eichenbaum, and Charles L. Evans [1999]: "Monetary Policy Shocks: What Have We Learned and to What End?", in: Taylor, John B. and Michael Woodford, eds.: Handbook of Macroeconomics. Volume 1A. Handbooks in Economics, vol. 15. Amsterdam; New York and Oxford: Elsevier Science, North Holland, 65-148.

Cochrane, John H. [2001]: "Money as Stock", mimeo, University of Chicago

(http://www-gsb.uchicago.edu/fac/john.cochrane/research/Papers/)

Edelberg, Wendy, Martin Eichenbaum, and Jonas D.M. Fisher [1999]: "Understanding the Effects of a Shock to Government Purchases", Review of Economics Dynamics, pp. 166-206

Fatás, Antonio and Ilian Mihov [2001]: "The Effects of Fiscal Policy on Consumption and Employment: Theory and Evidence", mimeo, INSEAD

Faust, Jon [1998]: "The Robustness of Identified VAR Conclusions About Money, Board of Governors of the Federal Reserve System", Carnegie-Rochester Conference Series on Public Policy, 49, pp. 207-44

Favero, Carlo m[2002]: "How Do European Monetary and Fiscal Authorities Behave?", CEPR Discussion paper, No. 3426, June

Giavazzi, Francesco, Tullio Jappelli, and Marco Pagano [2000]: "Searching for Non-Linear Effects of Fiscal Policy: evidence from Industrial and Developing Countries", European Economic Review 44, pp. 1259-1289

Giorno, Claude, Pete Richardson, Deborah Roseveare, and Paul van den Noord [1995]: "Estimating Potential Output, Output Gaps, and Structural Budget Deficits", Economic Department Working Paper 152, OECD, Paris

Jones, John B. [2002]: "Has Fiscal Policy Helped Stabilize the Postwar U.S. Economy?", Journal of Monetary Economics

Leeper, Eric M., Cristopher A. Sims, and Tao Zha [1996]: "What Does Monetary Policy Do?" Brookings Papers on Economic Activity, 0(2), 163

Marcellino, Massimiliano [2002]: "Some Stylized Facts on Non-Systematic Fiscal Policy in Europe", Bocconi University, Milan; 
Mountford, Andrew and Harald Uhlig [2002]: "What Are the Effcets of Fiscal Policy Shocks?" CEPR Discussion Paper 3338

Organization for Economic Cooperation and Development [1996]: Employment Outlook, Paris

Perotti, Roberto [1999]: "Fiscal Policy in Good Times and Bad", Quarterly Journal of Economics; 114(4), November, 13991436.

Perotti, Roberto [2002]: "A Quarterly Database on Fiscal Policy in 5 OECD Countries", in preparation, European UniversityInstitute

Persson, Mats, Torsten Persson, and Lars E. O. Svensson [1998]: "Debt, Cash Flow and Inflation Incentives: A Swedish Example", in Mervin King and Guillermo Calvo, eds.: The Debt Burden and its Consequences for Monetary Policy, London: MacMillan, pp. 28-62.

Ramey, Valerie A and Matthew D. Shapiro [1998]: "Costly Capital Reallocation and the Effects of Government Spending", National Bureau of Economic Research Working Paper: 6283, November

Romer, Christina D. and David H. Romer [1989]: "Does Monetary Policy Matter? A New Test in the Spirit of Friedman and Schwartz", in Olivier J. Blanchard and Stanley Fischer, eds.: NBER macroeconomics annual: 1989. Cambridge, Mass. and London: MIT Press, 12170.

Rudebusch, Glenn D [1998]: "Do Measures of Monetary Policy in a VAR Make Sense?", International Economic Review, 39(4), November, 90731

Sims, Christopher A. [1988]: "Identifying Policy Effects", in: Bryant, Ralph. C., Dale. W Henderson, Gerald Holtman, Peter Hooper, and Steven A. Symansky, eds.: Empirical Macroeconomics for Independent Economies, The Brookings Institutions, Washington, D.C., 305-321;

Sims, Christopher A. [1994]: "A Simple Model for the Determination of the Price Level and the Interaction of Monetary and Fiscal Policy", Economic Theory 4, pp. 381-99

Sims, Christopher A. [1997]: "Fiscal Foundations of Price Stability in Open Economies", mimeo, Yale University;

Sims, Christopher [1998]: "Econometric implications of the government budget constraint", Journal of Econometrics, 83, 9-19; 
Sims, Christopher [1999]: "The precarious fiscal foundations of EMU", mimeo;

Sims, Christopher A. and Tao Zha [1998]: "Bayesian Methods for Dynamic Multivariate Models", International Economic Review; 39(4), November, 949-68.

Stock, James H. and Mark W. Watson [2001]: "Vector Autoregressions", Journal of Economic Perspectives, November

Stock, James H. and Mark W. Watson [2002]: "Has the Business Cycle Changed and Why?", mimeo, Harvard University

Taylor, John B. [1996]: "Monetary Policy Implications of Greater Fiscal Discipline", in: Budget Deficits and Debt: Issues and Options, Federal reserve Bank of Kansas City

Taylor, John B. [2000]: "Reassessing Discretionary Fiscal Policy", mimeo, Stanford University

Uhlig, Harald, What are the Effects of Monetary Policy on Output? Results from an Agnostic Identification Procedure, Centre for Economic Policy Research Discussion Paper: 2137, May 1999, pages 44.

van den Noord, Paul [2002]: "Automatic Stabilizers in the 1990s and Beyond", in: Marco Buti, Jurgen von Hagen, and Carlos Martinez-Mongay, eds.: The Behavior of Fiscal Authorities: Stabilization, Growth and Institutions, Palgrave

Woodford, Michael [1998]: "Public debt and the price level", mimeo (http://www.princeton.edu/ woodford)

Woodford, Michael [1999]: "Price level determination under interest rate rules", mimeo (http://www.princeton.edu/ ${ }^{\text {woodford) }}$

Woodford, Michael [2001]: "Fiscal Requirements for Price Stability", NBER Working paper 8072 


\section{Table 1: Tax elasticities}

\begin{tabular}{|c|c|c|c|}
\hline & & etaxy & etaxp \\
\hline \multirow[t]{3}{*}{ USA } & all & 1.95 & 1.23 \\
\hline & to1979 & 1.94 & 1.10 \\
\hline & 1980on & 1.96 & 1.35 \\
\hline \multirow[t]{3}{*}{ DEU } & all & 0.90 & 0.98 \\
\hline & to1979 & 0.90 & 0.91 \\
\hline & 1980on & 0.99 & 1.06 \\
\hline \multirow[t]{3}{*}{ GBR } & all & 0.79 & 1.17 \\
\hline & to1979 & 0.65 & 1.06 \\
\hline & 1980on & 0.90 & 1.26 \\
\hline \multirow[t]{3}{*}{ CAN } & all & 1.92 & 1.09 \\
\hline & to1979 & 1.67 & 1.09 \\
\hline & 1980on & 2.22 & 1.09 \\
\hline \multirow[t]{3}{*}{ AUS } & all & 0.10 & 1.00 \\
\hline & to1979 & 0.08 & 0.96 \\
\hline & 1980on & 0.11 & 1.04 \\
\hline
\end{tabular}


Table 2: Chow tests

\begin{tabular}{llll}
\hline & & $\begin{array}{c}\text { Chow } \\
\text { test }\end{array}$ & Pval \\
\hline \hline USA & G & 1.36 & 0.15 \\
& $\mathbf{T}$ & 2.58 & 0.00 \\
& $\mathbf{Y}$ & 1.57 & 0.07 \\
& $\mathbf{P}$ & 2.56 & 0.00 \\
& $\mathbf{i}$ & 2.88 & 0.00 \\
DEU & $\mathbf{G}$ & 1.51 & 0.10 \\
& $\mathbf{T}$ & 1.36 & 0.17 \\
& $\mathbf{Y}$ & 1.18 & 0.29 \\
& $\mathbf{P}$ & 1.42 & 0.14 \\
& $\mathbf{i}$ & 1.41 & 0.14 \\
& & & \\
GBR & $\mathbf{G}$ & 1.76 & 0.03 \\
& $\mathbf{T}$ & 2.32 & 0.00 \\
& $\mathbf{Y}$ & 1.21 & 0.26 \\
& $\mathbf{P}$ & 1.83 & 0.02 \\
& $\mathbf{i}$ & 1.19 & 0.28 \\
& & & \\
CAN & $\mathbf{G}$ & 1.44 & 0.11 \\
& $\mathbf{T}$ & 2.41 & 0.00 \\
& $\mathbf{Y}$ & 2.03 & 0.01 \\
& $\mathbf{P}$ & 1.99 & 0.01 \\
& $\mathbf{i}$ & 1.23 & 0.24
\end{tabular}

$\begin{array}{llll}\text { AUS } & \mathbf{G} & 1.44 & 0.12 \\ & \mathbf{T} & 2.73 & 0.00 \\ & \mathbf{Y} & 1.24 & 0.23 \\ & \mathbf{P} & 2.41 & 0.00 \\ & \mathbf{i} & 0.96 & 0.52\end{array}$

The table displays the statistics from a Chow test on each reduced form equation, with the associated $p$-value. The test statistic is distributed according to the Fdistribution, with the following degrees of freedom:

USA: $F(21,118)$; West Germany: $F(21,74)$; UK: $\quad F(21,110)$; Canada: $\quad F(21,118)$; Australia: $F(21,105)$

Breakpoint for tests: 1980:1 (Germany: 1975:1) 


\section{Table 3: Effects of $\mathbf{G}$ on $Y$}

\begin{tabular}{llrrrrrr}
\hline & & 1qrt & 4qrts & 12qrts & 20qrts & max & min \\
\hline \hline & & & & & & & \\
USA & all & $0.43^{*}$ & 0.29 & $0.97^{*}$ & $0.96^{*}$ & $1.05^{*}(15)$ & $0.29(4)$ \\
& to1979 & $0.73^{*}$ & 0.55 & $1.30^{*}$ & -0.62 & $1.57^{*}(10)$ & $-0.62(20)$ \\
& $\mathbf{1 9 8 0}$ on & 0.07 & 0.20 & -0.53 & $-1.26^{*}$ & $0.49(3)$ & $-1.26^{*}(20)$ \\
& & & & & & & \\
DEU & all & $1.30^{*}$ & $0.96^{*}$ & -0.02 & $0.94^{*}$ & $1.30^{*}(1)$ & $-0.27(10)$ \\
& to1979 & $1.65^{*}$ & $1.24^{*}$ & 0.21 & $1.06^{*}$ & $1.65^{*}(1)$ & $-0.18(9)$ \\
& 1980on & $0.80^{*}$ & $-0.72^{*}$ & -0.86 & -0.71 & $0.80^{*}(1)$ & $-1.55^{*}(7)$ \\
& & & & & & & \\
GBR & all & $0.30^{*}$ & -0.04 & 0.21 & 0.06 & $0.30^{*}(1)$ & $-0.04(4)$ \\
& to1979 & $0.46^{*}$ & -0.20 & 0.30 & $0.81^{*}$ & $0.91^{*}(17)$ & $-0.20(4)$ \\
& $\mathbf{1 9 8 0}$ on & $-0.18^{*}$ & -0.23 & $-1.30^{*}$ & $-1.08^{*}$ & $-0.01(3)$ & $-1.52^{*}(15)$ \\
& & & & & & & \\
CAN & all & $0.42^{*}$ & 0.06 & 0.24 & 0.18 & $0.46^{*}(2)$ & $0.06(4)$ \\
& to1979 & $0.62^{*}$ & 0.01 & $0.81^{*}$ & $0.94^{*}$ & $0.94^{*}(17)$ & $0.01(4)$ \\
& 1980on & 0.07 & 0.17 & $-2.23^{*}$ & $-2.21^{*}$ & $0.17(3)$ & $-2.36^{*}(16)$ \\
& & & & & & & \\
AUS & all & $0.31^{*}$ & 0.01 & 0.27 & 0.20 & $0.31^{*}(1)$ & $-0.08(3)$ \\
& to1979 & 0.01 & 0.14 & 0.30 & $0.33^{*}$ & $0.51^{*}(5)$ & $-0.31(2)$ \\
& 1980on & $0.59^{*}$ & $0.47^{*}$ & $0.75^{*}$ & $0.62^{*}$ & $0.79^{*}(14)$ & $0.32^{*}(3)$ \\
& & & & & & & \\
\hline \hline
\end{tabular}

The table displays the effects on GDP of a shock to government spending equal to 1 percentage point of GDP. In parentheses beside the max and min response are the quarters at which they occur.

Model with 5 variables: G,T,Y,P,i

Elasticity of government spending to GDP deflator: -0.5 .

$A$ "*" indicates that 0 is outside the region between the two one-standard error bands. 


\begin{tabular}{|c|c|c|c|c|c|c|c|}
\hline \multicolumn{8}{|c|}{$\begin{array}{l}\text { Table 4: cumulative effects of G on G; cumulative output } \\
\text { multipliers }\end{array}$} \\
\hline & & $\begin{array}{l}\text { g_cum } \\
4 \text { qrts } \\
\end{array}$ & $\begin{array}{l}\text { g_cum } \\
12 \text { qrts } \\
\end{array}$ & $\begin{array}{l}\text { g_cum } \\
20 \text { qrts } \\
\end{array}$ & $\begin{array}{l}\text { y_cum/ } \\
\text { g_cum } \\
4 \text { qrts } \\
\end{array}$ & $\begin{array}{l}\text { y_cum/ } \\
\text { g_cum } \\
12 \text { qrts } \\
\end{array}$ & $\begin{array}{l}\text { y_cum/ } \\
\text { g_cum } \\
20 \text { qrts } \\
\end{array}$ \\
\hline USA & $\begin{array}{l}\text { all } \\
\text { to1979 } \\
\text { 1980on }\end{array}$ & $\begin{array}{l}3.55^{\star} \\
3.37^{\star} \\
2.71^{\star}\end{array}$ & $\begin{array}{l}8.66^{*} \\
6.53^{*} \\
6.62^{*}\end{array}$ & $\begin{array}{c}10.85^{*} \\
7.63^{*} \\
7.52^{*}\end{array}$ & $\begin{array}{l}0.47 \\
0.87 \\
0.26\end{array}$ & $\begin{array}{l}0.82 \\
2.08 \\
0.07\end{array}$ & $\begin{array}{r}1.40 \\
1.85 \\
-1.05\end{array}$ \\
\hline DEU & $\begin{array}{l}\text { all } \\
\text { to1979 } \\
1980 \text { on }\end{array}$ & $\begin{array}{l}3.54^{*} \\
3.00^{\star} \\
3.99^{\star}\end{array}$ & $\begin{array}{c}10.92^{\star} \\
7.39^{\star} \\
11.89^{\star}\end{array}$ & $\begin{array}{c}15.50^{*} \\
8.91^{*} \\
15.95^{\star}\end{array}$ & $\begin{array}{l}1.29 \\
1.95 \\
0.01\end{array}$ & $\begin{array}{c}0.41 \\
0.90 \\
-0.86\end{array}$ & $\begin{array}{r}0.59 \\
1.47 \\
-0.94\end{array}$ \\
\hline GBR & $\begin{array}{l}\text { all } \\
\text { to1979 } \\
\text { 1980on }\end{array}$ & $\begin{array}{l}3.40^{*} \\
3.24^{*} \\
3.24^{*}\end{array}$ & $\begin{array}{l}7.98^{\star} \\
7.19^{\star} \\
5.67^{\star}\end{array}$ & $\begin{array}{c}10.93^{*} \\
9.64^{*} \\
5.01^{*}\end{array}$ & $\begin{array}{c}0.20 \\
0.30 \\
-0.19\end{array}$ & $\begin{array}{c}0.29 \\
0.20 \\
-1.17\end{array}$ & $\begin{array}{c}0.30 \\
0.80 \\
-3.52\end{array}$ \\
\hline CAN & $\begin{array}{l}\text { all } \\
\text { to1979 } \\
1980 \text { on }\end{array}$ & $\begin{array}{l}2.94^{*} \\
2.34^{*} \\
2.93^{\star}\end{array}$ & $\begin{array}{l}7.27^{\star} \\
5.27^{\star} \\
7.70^{\star}\end{array}$ & $\begin{array}{c}10.83^{*} \\
7.53^{*} \\
9.76^{*}\end{array}$ & $\begin{array}{l}0.40 \\
0.76 \\
0.15\end{array}$ & $\begin{array}{r}0.43 \\
1.23 \\
-1.43\end{array}$ & $\begin{array}{c}0.45 \\
1.83 \\
-3.03\end{array}$ \\
\hline AUS & $\begin{array}{l}\text { all } \\
\text { to1979 } \\
1980 \text { on }\end{array}$ & $\begin{array}{l}2.89^{\star} \\
2.18^{\star} \\
2.59^{\star}\end{array}$ & $\begin{array}{l}6.20^{\star} \\
5.08^{\star} \\
5.15^{\star}\end{array}$ & $\begin{array}{l}8.10^{*} \\
5.98^{\star} \\
6.10^{\star}\end{array}$ & $\begin{array}{c}0.08 \\
-0.09 \\
0.68\end{array}$ & $\begin{array}{l}0.31 \\
0.30 \\
1.28\end{array}$ & $\begin{array}{l}0.47 \\
0.77 \\
2.03\end{array}$ \\
\hline
\end{tabular}

$\overline{\text { The table displays the cumulative effects on government spending of a shock to government }}$ spending equal to 1 percentage point of GDP (first 3 columns) and the cumulative multipliers from the same exercise (last 3 columns).

Model with 5 variables: G,T,Y,P,i.

Elasticity of government spending to GDP deflator: -0.5

$A^{\prime * 1}$ indicates that 0 is outside the region between the two one-standard error bands. 
Table 5: Cumulative government spending multipliers from macroeconometric models and VARs

\begin{tabular}{|c|c|c|c|c|}
\hline & & 1qrt & 4qrts & 12qrts \\
\hline \multicolumn{2}{|l|}{ DRI } & 1.53 & 2.05 & 1.86 \\
\hline \multicolumn{2}{|l|}{ EEC } & - & 1.18 & 1.10 \\
\hline \multicolumn{2}{|l|}{ EPA } & 1.14 & 1.57 & 1.63 \\
\hline \multicolumn{2}{|l|}{ LINK } & - & 1.24 & 1.14 \\
\hline \multicolumn{2}{|c|}{ LIVERPOOL } & - & 0.65 & 0.58 \\
\hline \multicolumn{2}{|c|}{$\mathrm{MCM}$} & 1.26 & 1.56 & 1.61 \\
\hline \multicolumn{2}{|c|}{ MINIMOD } & 1.09 & 1.11 & 0.94 \\
\hline \multicolumn{2}{|l|}{ MSG } & - & 0.97 & 0.85 \\
\hline \multicolumn{2}{|c|}{ OECD } & - & 1.53 & 1.07 \\
\hline \multicolumn{2}{|c|}{ TAYLOR } & 1.26 & 1.64 & 0.93 \\
\hline \multicolumn{2}{|c|}{ WHARTON } & - & 1.78 & 1.56 \\
\hline \multirow[t]{2}{*}{ USA } & to1979 & 0.27 & 0.87 & 2.08 \\
\hline & 1980on & 0.14 & 0.26 & 0.07 \\
\hline \multirow[t]{2}{*}{ DEU } & to1979 & 0.17 & 1.95 & 0.90 \\
\hline & 1980on & 0.35 & 0.01 & -0.86 \\
\hline \multirow[t]{2}{*}{ GBR } & to1979 & -0.03 & 0.30 & 0.20 \\
\hline & 1980on & 0.26 & -0.19 & -1.17 \\
\hline \multirow[t]{2}{*}{ CAN } & to1979 & 0.01 & 0.76 & 1.23 \\
\hline & 1980on & -0.03 & 0.15 & -1.43 \\
\hline \multirow[t]{2}{*}{ AUS } & to1979 & 0.77 & -0.09 & 0.3 \\
\hline & 1980on & -0.17 & 0.68 & 1.28 \\
\hline
\end{tabular}

$\overline{\text { The first panel displays the cumulative multipliers from } 11 \text { macroeconometric }}$ models, as displayed in Sims [1988]. The second panel displays the cumulative multipliers from a 5 variable VAR, as In Table 4. 


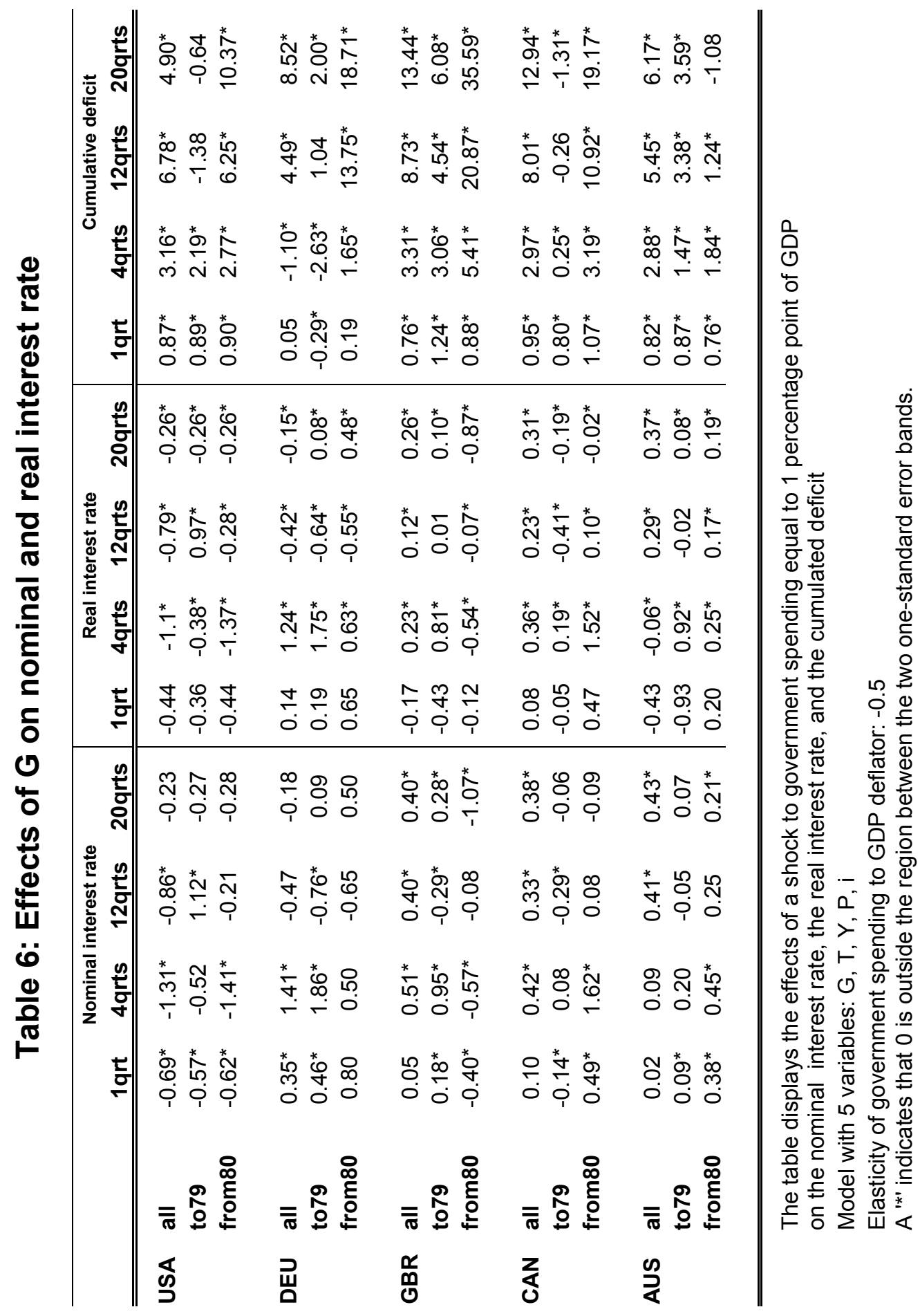




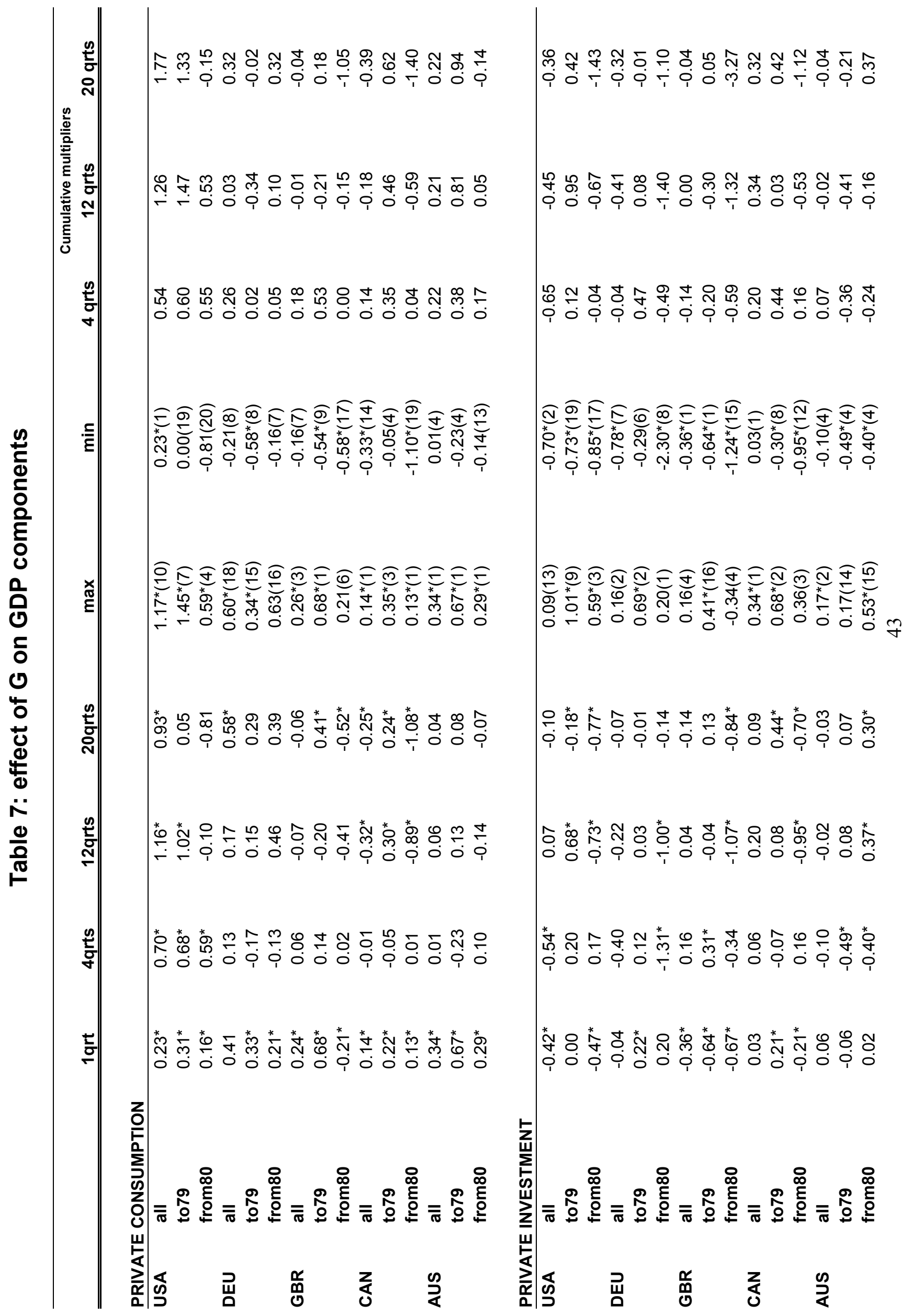




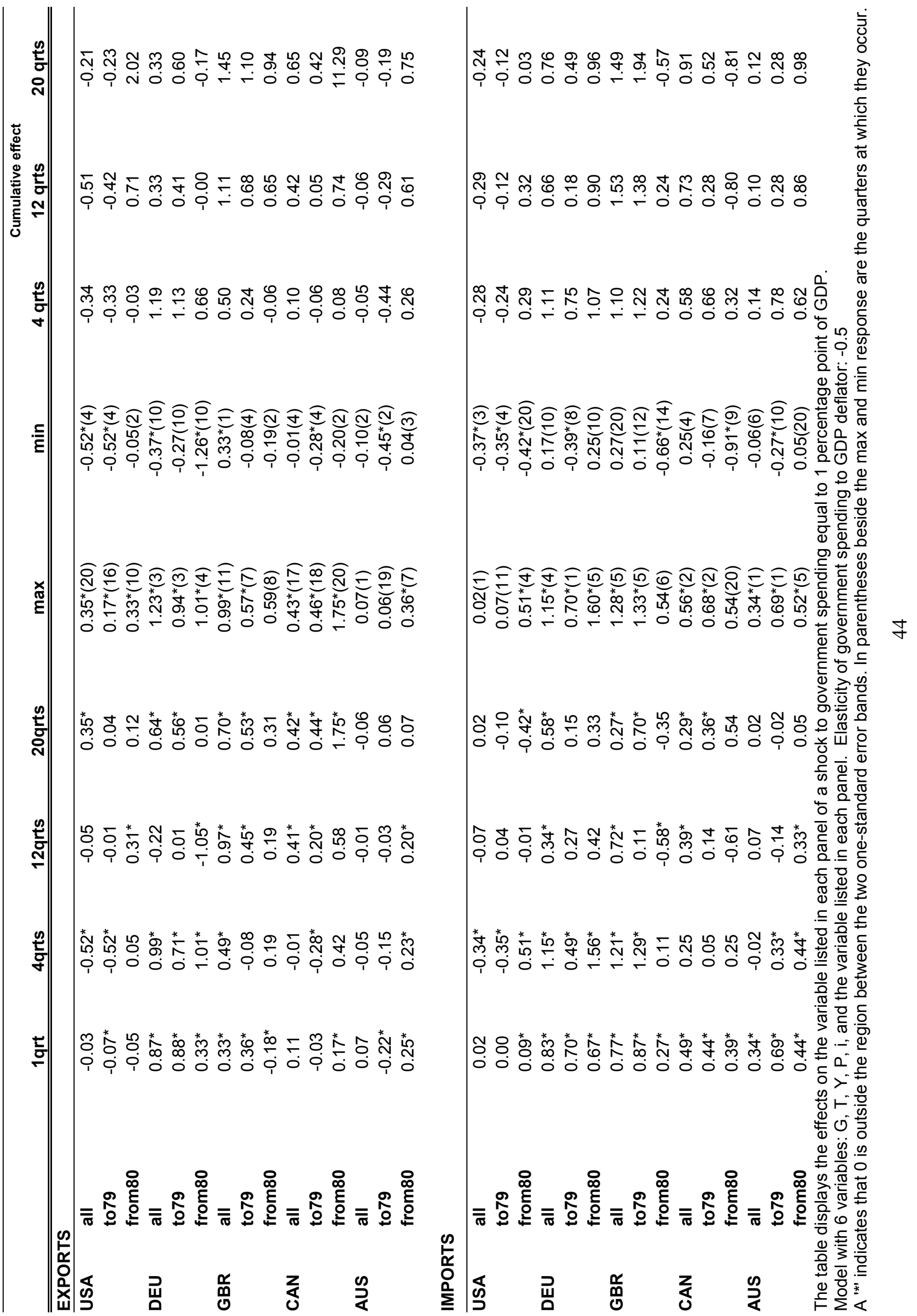




\section{Table 8: Effects of $\mathbf{G}$ on $\mathbf{P}$}

\begin{tabular}{|c|c|c|c|c|c|c|}
\hline & & 1qrt & 4qrts & 12qrts & $20 \mathrm{qrts}$ & egcnp \\
\hline \multirow[t]{3}{*}{ USA } & all & $-0.12^{*}$ & $-0.80^{*}$ & $-2.08^{*}$ & $-2.30^{*}$ & 0.0 \\
\hline & to1979 & -0.00 & $-0.41^{*}$ & $-0.69^{*}$ & 0.24 & 0.0 \\
\hline & 1980 on & $-0.23^{*}$ & $-0.59^{*}$ & -0.26 & 0.03 & 0.0 \\
\hline \multirow[t]{3}{*}{ USA } & all & -0.01 & $-0.55^{\star}$ & $-1.63^{*}$ & $-1.81^{*}$ & -0.5 \\
\hline & to1979 & $0.10^{*}$ & -0.27 & $-0.63^{*}$ & 0.35 & -0.5 \\
\hline & 1980 on & -0.16 & $-0.48^{*}$ & -0.17 & 0.07 & -0.5 \\
\hline \multirow[t]{3}{*}{ DEU } & all & 0.09 & $0.87^{*}$ & $1.57^{\star}$ & $1.22^{*}$ & 0.0 \\
\hline & to1979 & 0.03 & $0.88^{*}$ & $1.19^{*}$ & 0.73 & 0.0 \\
\hline & 1980on & 0.08 & 0.35 & -0.21 & -0.44 & 0.0 \\
\hline \multirow[t]{3}{*}{ DEU } & all & $0.25^{\star}$ & $1.06^{\star}$ & $1.72^{*}$ & $1.32^{*}$ & -0.5 \\
\hline & to1979 & $0.22^{*}$ & $1.10^{*}$ & $1.39^{*}$ & 0.91 & -0.5 \\
\hline & 1980 on & 0.28 & 0.48 & -0.23 & -0.38 & -0.5 \\
\hline \multirow[t]{3}{*}{ GBR } & all & $-0.48^{*}$ & -0.12 & $2.11^{*}$ & $3.98^{*}$ & 0.0 \\
\hline & to1979 & $-0.92^{*}$ & -0.48 & -0.08 & -1.00 & 0.0 \\
\hline & 1980on & $-0.15^{*}$ & 0.06 & $1.20^{*}$ & 0.28 & 0.0 \\
\hline \multirow[t]{3}{*}{ GBR } & all & -0.02 & $0.66^{*}$ & $3.24^{*}$ & $5.03^{*}$ & -0.5 \\
\hline & to1979 & $-0.49^{*}$ & 0.27 & 0.78 & -0.29 & -0.5 \\
\hline & 1980on & $0.21^{*}$ & 0.26 & $1.13^{*}$ & 0.16 & -0.5 \\
\hline \multirow[t]{3}{*}{ CAN } & all & $-0.29^{*}$ & -0.23 & 0.41 & $1.26^{*}$ & 0.0 \\
\hline & to1979 & $-0.21^{*}$ & -0.25 & -0.06 & $1.17^{*}$ & 0.0 \\
\hline & 1980on & $-0.48^{*}$ & -0.18 & 0.20 & -0.15 & 0.0 \\
\hline \multirow[t]{3}{*}{ CAN } & all & -0.08 & 0.17 & $0.90^{*}$ & $1.61^{*}$ & -0.5 \\
\hline & to1979 & -0.04 & 0.02 & 0.08 & $1.24^{*}$ & -0.5 \\
\hline & 1980on & $-0.27^{*}$ & 0.04 & 0.31 & -0.11 & -0.5 \\
\hline \multirow[t]{3}{*}{ AUS } & all & $-0.85^{*}$ & -0.10 & $1.02^{*}$ & $1.66^{*}$ & 0.0 \\
\hline & to1979 & $-1.60^{*}$ & 0.17 & -0.28 & -0.28 & 0.0 \\
\hline & 1980on & $-0.36^{*}$ & -0.38 & $0.74^{*}$ & $1.20^{*}$ & 0.0 \\
\hline \multirow[t]{3}{*}{ AUS } & all & -0.16 & $0.69^{*}$ & $2.09^{*}$ & $2.82^{*}$ & -0.5 \\
\hline & to1979 & $-0.34^{*}$ & $1.48^{*}$ & $1.25^{*}$ & 1.08 & -0.5 \\
\hline & 1980on & $-0.21^{*}$ & -0.24 & $0.79^{*}$ & $1.21^{*}$ & -0.5 \\
\hline
\end{tabular}

The table displays the effects on the GDP deflator of a shock to government spending equal to 1 percentage point of GDP.

Model with 5 variables: $G, T, Y, P, i$.

The elasticity of government spending to the GDP deflator is displayed in the last column. $A^{\prime * \prime}$ indicates that 0 is outside the region between the two one-standard error bands. 


\section{Table 9: Effects of G on CPI}

\begin{tabular}{llllll}
\hline & & 1qrt & 4qrts & 12qrts & 20qrts \\
\hline \hline \multirow{2}{*}{ USA } & all & & & & \\
& to1979 & $0.20^{*}$ & -0.18 & $-1.94^{*}$ & $-2.51^{*}$ \\
& 1980 on & $0.27^{*}$ & 0.06 & -0.11 & $1.05^{*}$ \\
& & 0.14 & -0.44 & 0.20 & 0.39 \\
DEU & all & & & & \\
& to1979 & $0.24^{*}$ & $0.96^{*}$ & $2.41^{*}$ & $2.68^{*}$ \\
& 1980 on & $0.17^{*}$ & $0.83^{*}$ & $2.42^{*}$ & $2.55^{*}$ \\
& & 0.35 & $1.22^{*}$ & $1.28^{*}$ & 0.85 \\
GBR & all & & & & \\
& to1979 & 0.12 & $1.35^{*}$ & $4.03^{*}$ & $5.25^{*}$ \\
& 1980 on & -0.03 & $1.77^{*}$ & $2.58^{*}$ & $2.14^{*}$ \\
& & $0.26^{*}$ & -0.14 & $1.17^{*}$ & 0.04 \\
\multirow{2}{*}{ CAN } & all & & & & \\
& to1979 & 0.02 & $-0.19^{*}$ & $-0.40^{*}$ & $-0.45^{*}$ \\
& 1980on & $0.01^{*}$ & $-0.09^{*}$ & $-0.29^{*}$ & $-0.22^{*}$ \\
& & -0.03 & -0.29 & 0.06 & -0.48 \\
AUS & all & & & & \\
& to1979 & $0.23^{*}$ & $0.78^{*}$ & $2.43^{*}$ & $3.25^{*}$ \\
& 1980 on & $0.77^{*}$ & $1.85^{*}$ & $2.62^{*}$ & $2.73^{*}$ \\
& & $-0.17^{*}$ & 0.33 & $1.21^{*}$ & $1.37^{*}$ \\
\hline \hline
\end{tabular}

The table displays the effects on the CPI of a shock to government spending equal to 1 percentage point of GDP.

Model with 5 variables: $G, T, Y, P, i$.

Elasticity of government spending to CPI: -0.5 . $A^{\prime * \prime}$ indicates that 0 is outside the region between the two one-standard error bands. 
Table 10: Effects of $T$ on $Y$

\begin{tabular}{|c|c|c|c|c|c|c|c|c|}
\hline & & 1qrt & 4qrts & 12qrts & 20qrts & $\max$ & $\min$ & etaxy \\
\hline \multirow[t]{3}{*}{ USA } & all & $-0.26^{*}$ & $-0.66^{*}$ & $-0.69^{*}$ & $-0.53^{*}$ & $-0.26^{*}(1)$ & $-0.75^{\star}(7)$ & 1.95 \\
\hline & to1979 & $-0.39^{*}$ & $-0.78^{*}$ & $-1.11^{*}$ & $-0.83^{*}$ & $-0.39^{*}(1)$ & $-1.12^{*}(13)$ & 1.94 \\
\hline & 1980on & $-0.17^{*}$ & $0.37^{*}$ & $0.79^{*}$ & -0.11 & $0.91^{*}(9)$ & $-0.17^{*}(1)$ & 1.96 \\
\hline \multirow[t]{3}{*}{ USA } & all & $-0.47^{*}$ & $-0.86^{*}$ & $-0.76^{*}$ & $-0.51^{*}$ & $-0.47^{\star}(1)$ & $-0.88^{\star}(6)$ & 2.95 \\
\hline & to1979 & $-0.54^{*}$ & $-0.80^{*}$ & $-0.98^{*}$ & $-0.86^{*}$ & $-0.34^{*}(1)$ & $-1.01^{*}(14)$ & 2.94 \\
\hline & 1980on & $-0.49^{*}$ & -0.03 & $0.62^{*}$ & -0.08 & $0.69^{*}(9)$ & $-0.49(20)$ & 2.96 \\
\hline \multirow[t]{3}{*}{ DEU } & all & $0.27^{\star}$ & $-0.46^{*}$ & $-0.51^{*}$ & 0.05 & $0.27^{\star}(1)$ & $-0.98^{\star}(7)$ & 0.90 \\
\hline & to1979 & $0.29^{*}$ & $-0.60^{*}$ & $-0.46^{*}$ & -0.10 & $0.29^{*}(1)$ & $-1.16^{*}(7)$ & 0.90 \\
\hline & 1980on & $0.24^{*}$ & $-0.49^{*}$ & -0.21 & -0.32 & $0.24^{*}(1)$ & $-0.61^{*}(7)$ & 0.99 \\
\hline \multirow[t]{3}{*}{ DEU } & all & $-0.17^{*}$ & $-0.99^{*}$ & $-0.78^{*}$ & -0.22 & $-0.17^{*}(1)$ & $-1.40^{*}(7)$ & 1.90 \\
\hline & to1979 & -0.08 & $-1.09^{*}$ & $-0.69^{*}$ & $-0.37^{*}$ & $-0.08(1)$ & $-1.58^{*}(7)$ & 1.90 \\
\hline & 1980on & 0.01 & $-0.66^{*}$ & -0.20 & $-0.39^{*}$ & $0.01(1)$ & $-0.66^{\star}(4)$ & 1.99 \\
\hline \multirow[t]{3}{*}{ GBR } & all & $0.06^{*}$ & 0.05 & $0.21^{*}$ & $0.24^{*}$ & $0.24^{*}(20)$ & $0.05(4)$ & 0.79 \\
\hline & to1979 & $0.05^{*}$ & $-0.19^{*}$ & 0.15 & $-0.13^{*}$ & $0.15(12)$ & $-0.19^{*}(4)$ & 0.65 \\
\hline & 1980on & $0.18^{*}$ & $0.34^{*}$ & 0.05 & -0.14 & $0.34^{*}(4)$ & $-0.14(20)$ & 0.90 \\
\hline \multirow[t]{3}{*}{ GBR } & all & -0.04 & -0.02 & $0.20^{*}$ & $0.23^{*}$ & $0.23^{\star}(20)$ & $-0.04(1)$ & 1.79 \\
\hline & to1979 & $-0.08^{*}$ & $-0.26^{*}$ & 0.11 & $-0.17^{*}$ & $0.11(12)$ & $-0.26^{*}(4)$ & 1.65 \\
\hline & 1980on & $0.12^{*}$ & $0.29^{*}$ & 0.03 & -0.17 & $0.29^{*}(4)$ & $-0.17(20)$ & 1.90 \\
\hline \multirow[t]{3}{*}{ CAN } & all & $-0.14^{*}$ & $-0.48^{*}$ & $-0.47^{*}$ & -0.06 & $-0.06(2)$ & $-0.61^{*}(8)$ & 1.92 \\
\hline & to1979 & $-0.18^{*}$ & $-0.28^{*}$ & $0.26^{*}$ & $0.28^{*}$ & $0.28^{*}(17)$ & $-0.28^{\star}(4)$ & 1.67 \\
\hline & 1980on & $-0.12^{*}$ & $-0.55^{\star}$ & $-0.44^{*}$ & -0.09 & $-0.09(20)$ & $-0.67^{*}(7)$ & 2.22 \\
\hline \multirow[t]{3}{*}{ CAN } & all & $-0.27^{*}$ & $-0.57^{*}$ & $-0.49^{*}$ & -0.10 & $-0.10(20)$ & $-0.65^{\star}(7)$ & 2.92 \\
\hline & to1979 & $-0.39^{*}$ & $-0.39^{*}$ & $0.19^{*}$ & $0.19^{*}$ & $0.21^{*}(14)$ & $-0.39^{\star}(4)$ & 2.67 \\
\hline & 1980on & $-0.22^{*}$ & $-0.60^{*}$ & $-0.37^{*}$ & -0.02 & $-0.02(20)$ & $-0.65^{\star}(7)$ & 3.22 \\
\hline \multirow[t]{3}{*}{ AUS } & all & $0.60^{*}$ & $0.44^{*}$ & 0.13 & -0.04 & $0.60^{\star}(1)$ & $-0.04(20)$ & 0.10 \\
\hline & to1979 & $0.54^{*}$ & -0.09 & -0.01 & 0.05 & $0.54^{*}(1)$ & $-0.12(3)$ & 0.08 \\
\hline & 1980on & $0.41^{*}$ & $0.55^{*}$ & 0.20 & -0.14 & $0.56^{\star}(7)$ & $-0.14(20)$ & 0.11 \\
\hline \multirow[t]{3}{*}{ AUS } & all & $0.38^{*}$ & $0.31^{*}$ & 0.05 & -0.12 & $0.42^{*}(2)$ & $-0.12(20)$ & 1.10 \\
\hline & to1979 & -0.00 & $-0.36^{*}$ & -0.17 & -0.08 & $-0.00(1)$ & $-0.36^{\star}(4)$ & 1.08 \\
\hline & 1980on & $0.25^{\star}$ & $0.40^{*}$ & 0.12 & -0.21 & $0.46^{*}(7)$ & $-0.21(20)$ & 1.11 \\
\hline
\end{tabular}

The table displays the effects on GDP of a shock to net taxes equal to 1 percentage point of GDP. In parentheses beside the max and min response are the quarters at which they occur. The output elasticities of net taxes are displayed in the last column

Model with 5 variables: G,T,Y,P,i. Elasticity of government spending to GDP deflator: -0.5 . A ${ }^{1 * 1}$ indicates that 0 is outside the region between the two one-standard error bands. 


\section{Table 11: Cumulative effects of $\mathrm{T}$ on $\mathrm{T}$; cumulative tax multipliers}

\begin{tabular}{|c|c|c|c|c|c|c|c|}
\hline & & $\begin{array}{c}t \text { _cum } \\
4 \text { qrts } \\
\end{array}$ & $\begin{array}{l}\mathrm{t} \text { _cum } \\
12 \text { qrts } \\
\end{array}$ & $\begin{array}{l}\text { t_cum } \\
20 \text { qrts }\end{array}$ & $\begin{array}{c}\text { y_cum/ } \\
\text { t_cum } \\
4 \text { qrts } \\
\end{array}$ & $\begin{array}{c}\text { y_cum/ } \\
\text { t_cum } \\
12 \text { qrts } \\
\end{array}$ & $\begin{array}{c}\text { y_cum/ } \\
\text { t_cum } \\
20 \text { qrts } \\
\end{array}$ \\
\hline \multirow[t]{3}{*}{ USA } & all & $1.79^{*}$ & $1.71^{*}$ & 1.57 & -0.88 & -4.31 & -7.75 \\
\hline & to1979 & $1.27^{*}$ & -0.05 & $-2.69^{*}$ & -1.75 & 177.92 & 6.58 \\
\hline & 1980on & $2.23^{*}$ & $5.70^{*}$ & $7.81^{*}$ & 0.27 & 1.24 & 1.22 \\
\hline \multirow[t]{3}{*}{ DEU } & all & $3.28^{*}$ & $1.80^{*}$ & 1.36 & -0.08 & -3.62 & -5.47 \\
\hline & to1979 & $3.08^{*}$ & 0.29 & -0.32 & -0.22 & -26.68 & 27.82 \\
\hline & 1980on & $2.55^{*}$ & 0.93 & 0.85 & -0.18 & -4.04 & -5.63 \\
\hline \multirow[t]{3}{*}{ GBR } & all & $2.18^{*}$ & $4.82^{*}$ & $6.31^{*}$ & 0.14 & 0.37 & 0.57 \\
\hline & to1979 & $1.72^{*}$ & $1.68^{*}$ & $1.75^{*}$ & -0.11 & 0.04 & 0.03 \\
\hline & 1980on & $1.94^{*}$ & $4.22^{*}$ & $4.04^{*}$ & 0.51 & 0.56 & 0.44 \\
\hline \multirow[t]{3}{*}{ CAN } & all & $2.51^{*}$ & $4.72^{*}$ & $6.79^{*}$ & -0.37 & -1.14 & -1.07 \\
\hline & to1979 & $1.32^{*}$ & $2.57^{\star}$ & $3.99^{*}$ & -0.44 & 0.03 & 0.58 \\
\hline & 1980on & $2.47^{*}$ & $2.67^{*}$ & 1.51 & -0.41 & -2.08 & -4.93 \\
\hline \multirow[t]{3}{*}{ AUS } & all & $2.25^{*}$ & $4.33^{*}$ & $4.87^{*}$ & 0.9 & 1.02 & 0.93 \\
\hline & to1979 & $0.67^{*}$ & $1.06^{*}$ & $1.16^{*}$ & 0.59 & 0.99 & 1.02 \\
\hline & 1980on & $2.98^{*}$ & $7.15^{\star}$ & $8.26^{*}$ & 0.6 & 0.72 & 0.59 \\
\hline
\end{tabular}

The table displays the cumulative effects on net taxes of a shock to net taxes equal to 1 percentage point of GDP (first 3 columns) and the cumulative net tax multipliers from the same exercise (last 3 columns).

Model with 5 variables: $G, T, Y, P, i$.

Elasticity of government spending to GDP deflator: -0.5

$A^{\prime * \prime}$ indicates that 0 is outside the region between the two one-standard error bands. 


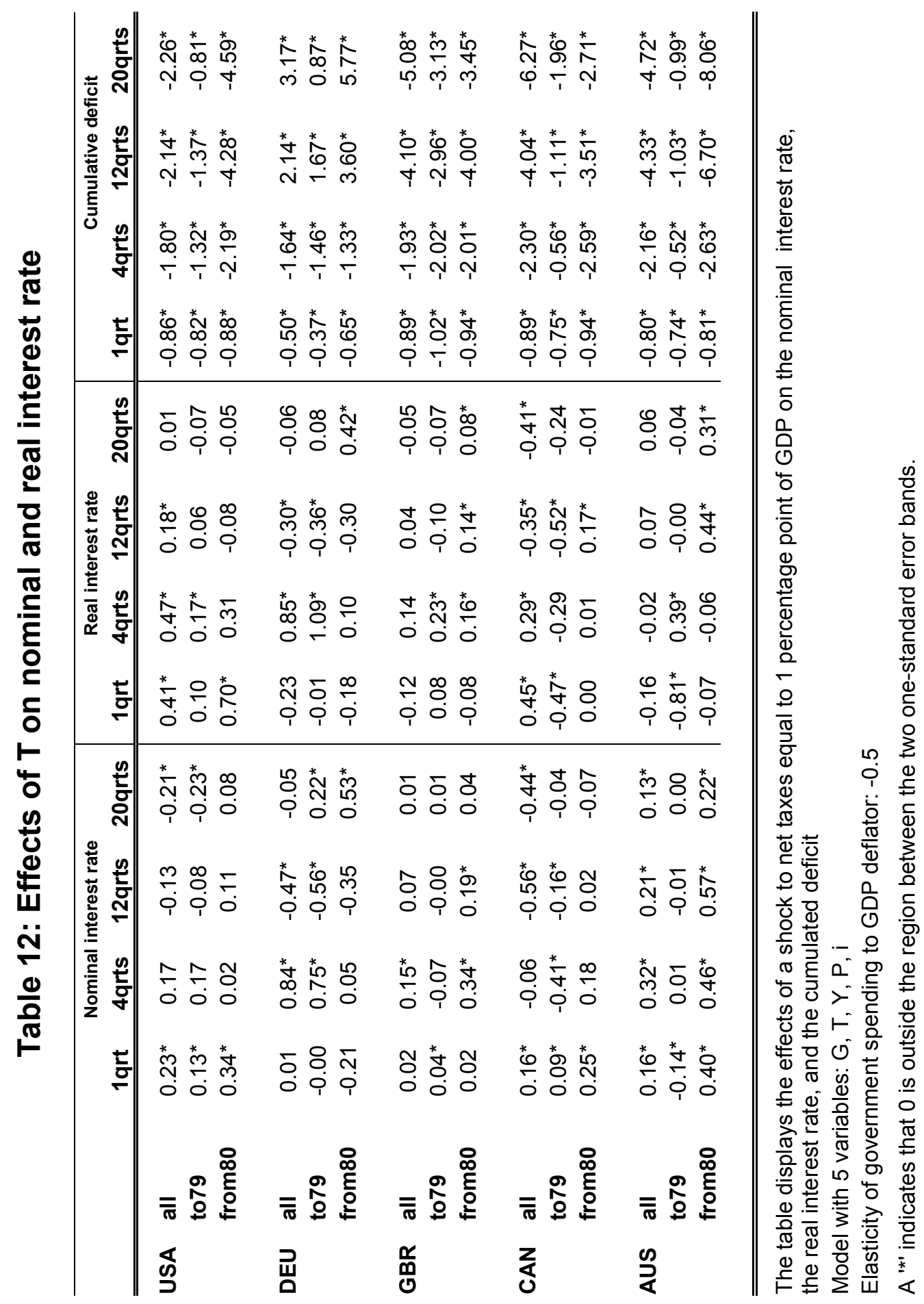


Table 13: Effects of $T$ on $P$

\begin{tabular}{|c|c|c|c|c|c|c|}
\hline & & 1qrt & 4qrts & 12qrts & 20qrts & etaxp \\
\hline \multirow[t]{3}{*}{ USA } & all & 0.00 & -0.12 & $-0.74^{*}$ & $-1.32^{*}$ & 1.23 \\
\hline & to1979 & $0.02^{*}$ & 0.05 & 0.01 & $-0.31^{*}$ & 1.10 \\
\hline & 1980on & -0.02 & $-0.27^{*}$ & $-0.53^{*}$ & -0.13 & 1.35 \\
\hline \multirow[t]{3}{*}{ USA } & all & 0.02 & -0.08 & $-0.67^{*}$ & $-1.24^{*}$ & 0.73 \\
\hline & to1979 & $0.04^{*}$ & 0.07 & 0.02 & $-0.30^{*}$ & 0.60 \\
\hline & 1980on & -0.00 & $-0.24^{*}$ & $-0.51^{*}$ & -0.12 & 0.85 \\
\hline \multirow[t]{3}{*}{ DEU } & all & -0.07 & $0.17^{*}$ & 0.00 & -0.25 & 0.98 \\
\hline & to1979 & $-0.08^{*}$ & 0.02 & $-0.68^{*}$ & $-0.83^{*}$ & 0.91 \\
\hline & 1980on & $-0.19^{*}$ & -0.16 & -0.37 & -0.29 & 1.06 \\
\hline \multirow[t]{3}{*}{ DEU } & all & -0.01 & $0.24^{*}$ & $0.05^{*}$ & -0.21 & 0.48 \\
\hline & to1979 & -0.02 & $0.08^{*}$ & $-0.63^{*}$ & $-0.79^{*}$ & 0.41 \\
\hline & 1980on & $-0.16^{*}$ & -0.15 & $-0.39^{*}$ & -0.29 & 0.56 \\
\hline \multirow[t]{3}{*}{ GBR } & all & $-0.17^{*}$ & -0.01 & 0.04 & 0.10 & 1.17 \\
\hline & to1979 & $-0.21^{*}$ & $-0.20^{*}$ & $-0.93^{*}$ & $-0.48^{*}$ & 1.06 \\
\hline & 1980on & $-0.24^{*}$ & $-0.16^{*}$ & $0.14^{*}$ & $0.19^{*}$ & 1.26 \\
\hline \multirow[t]{3}{*}{ GBR } & all & $-0.13^{*}$ & 0.07 & 0.15 & 0.21 & 0.67 \\
\hline & to1979 & $-0.16^{*}$ & -0.12 & $-0.88^{*}$ & -0.42 & 0.56 \\
\hline & 1980on & $-0.22^{*}$ & $-0.14^{*}$ & $0.14^{*}$ & $0.19^{*}$ & 0.76 \\
\hline \multirow[t]{3}{*}{ CAN } & all & $-0.11^{*}$ & $-0.31^{*}$ & $-0.97^{*}$ & $-1.29^{*}$ & 1.09 \\
\hline & to1979 & $-0.16^{*}$ & $-0.49^{*}$ & $-0.41^{*}$ & 0.26 & 1.09 \\
\hline & 1980on & -0.08 & 0.11 & 0.22 & -0.05 & 1.09 \\
\hline \multirow[t]{3}{*}{ CAN } & all & $-0.07^{*}$ & $-0.24^{*}$ & $-0.89^{*}$ & $-1.25^{\star}$ & 0.59 \\
\hline & to1979 & $-0.11^{*}$ & $-0.41^{*}$ & -0.37 & 0.28 & 0.59 \\
\hline & 1980on & -0.05 & 0.15 & 0.24 & -0.05 & 0.59 \\
\hline \multirow[t]{3}{*}{ AUS } & all & $-0.55^{\star}$ & $-0.45^{*}$ & 0.05 & 0.29 & 1.00 \\
\hline & to1979 & $-1.07^{*}$ & $-0.80^{*}$ & -0.30 & -0.30 & 0.96 \\
\hline & 1980on & $-0.19^{*}$ & 0.06 & $0.84^{*}$ & $0.96^{*}$ & 1.04 \\
\hline \multirow[t]{3}{*}{ AUS } & all & $-0.38^{*}$ & $-0.25^{\star}$ & 0.37 & 0.65 & 0.50 \\
\hline & to1979 & $-0.77^{\star}$ & $-0.48^{*}$ & 0.20 & 0.13 & 0.46 \\
\hline & 1980on & -0.13 & 0.12 & $0.88^{*}$ & $0.98^{*}$ & 0.54 \\
\hline
\end{tabular}

The table displays the effects on the GDP deflator of a shock to net taxes equal to 1 percentage point of GDP.

Model with 5 variables: $G, T, Y, P, i$.

The elasticity of net taxes to the GDP deflator is displayed in the last column. A ${ }^{1 * 1}$ indicates that 0 is outside the region between the two one-standard error bands. 
Figure 1 - $G$ and T shocks, USA
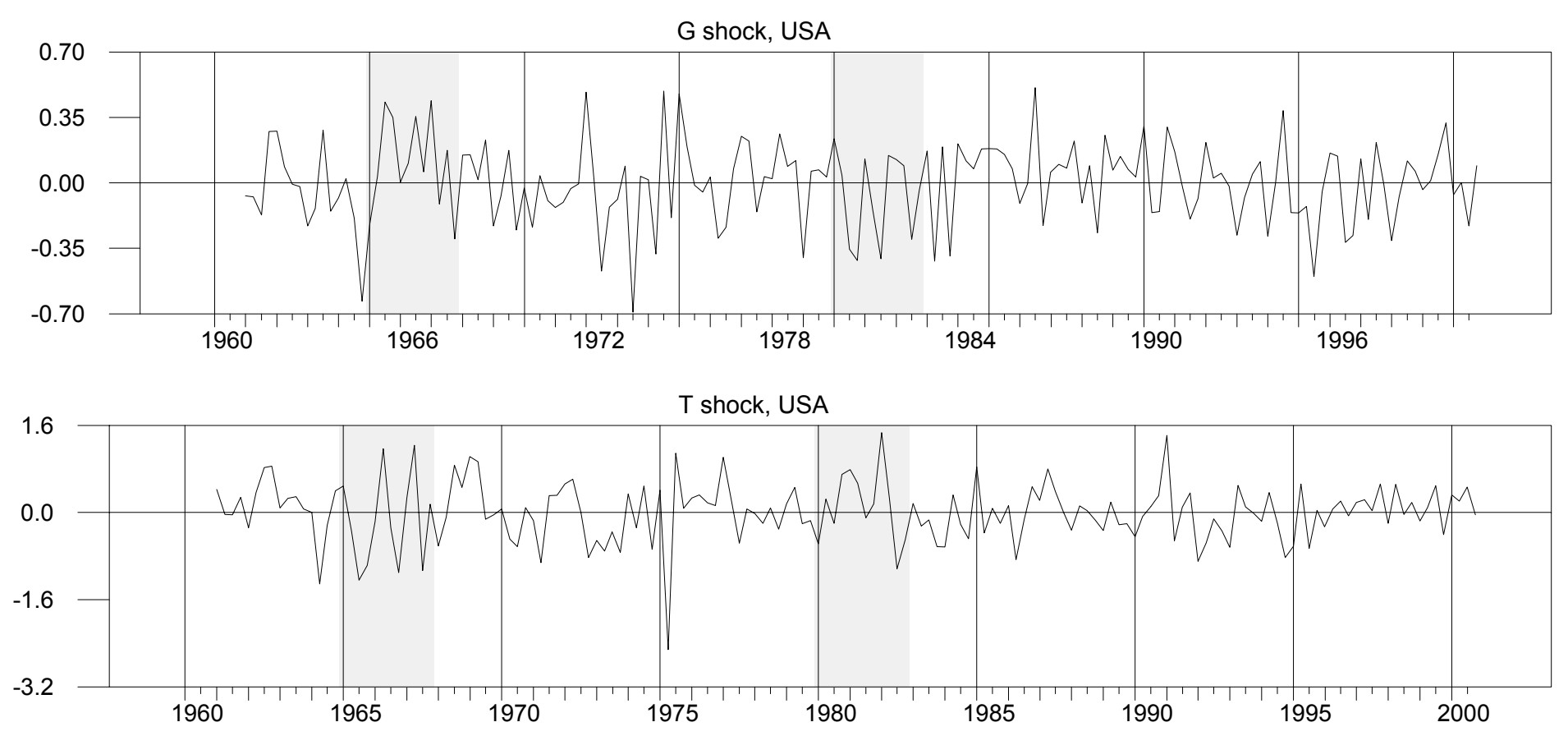


\section{Figure 2 - Response of $Y$ to $\mathbf{G}$}
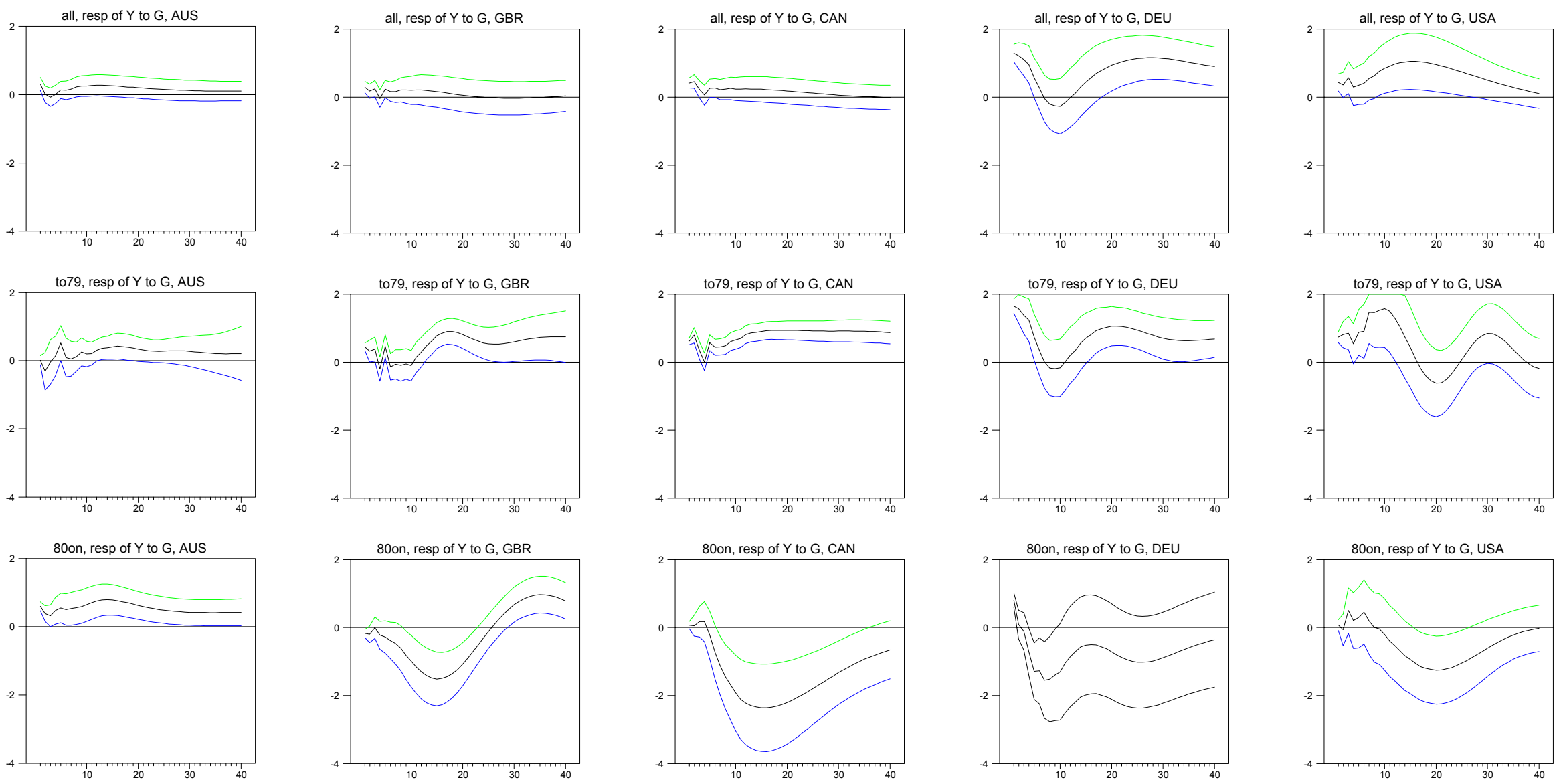
Figure 3 - Response of $Y$ to $T$
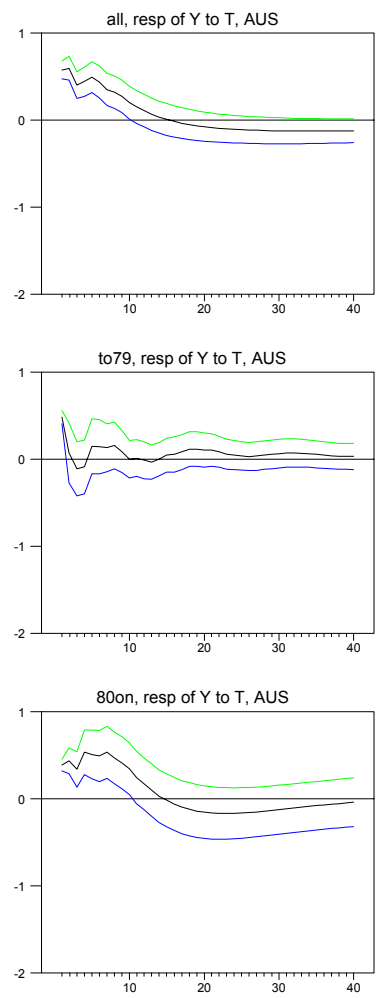
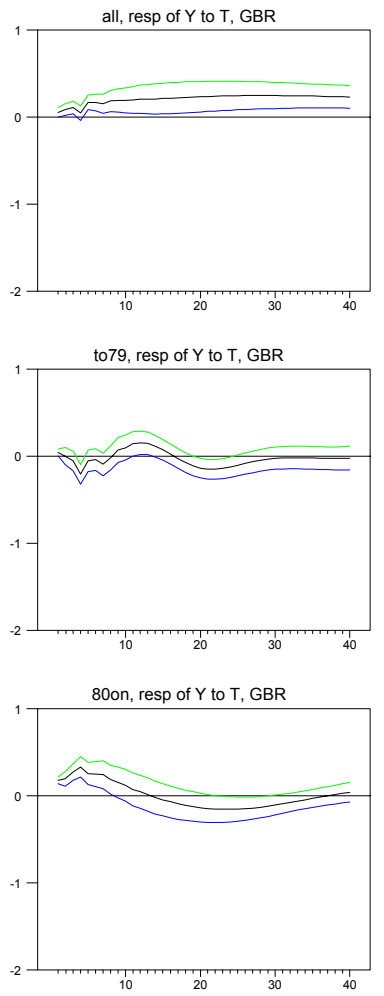
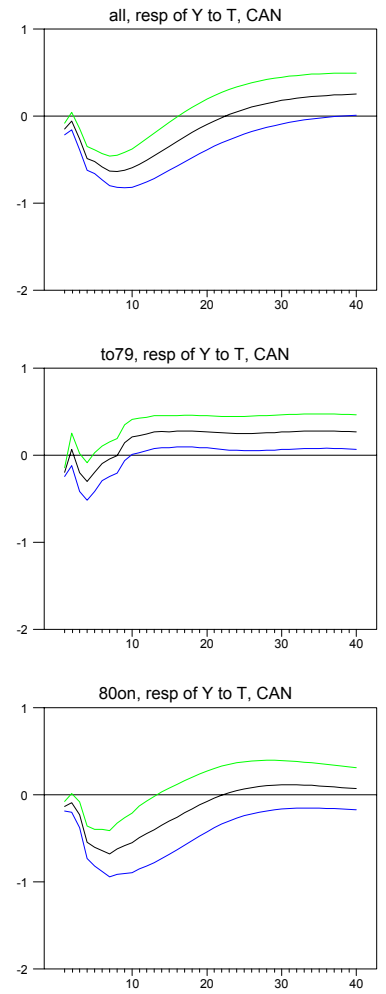
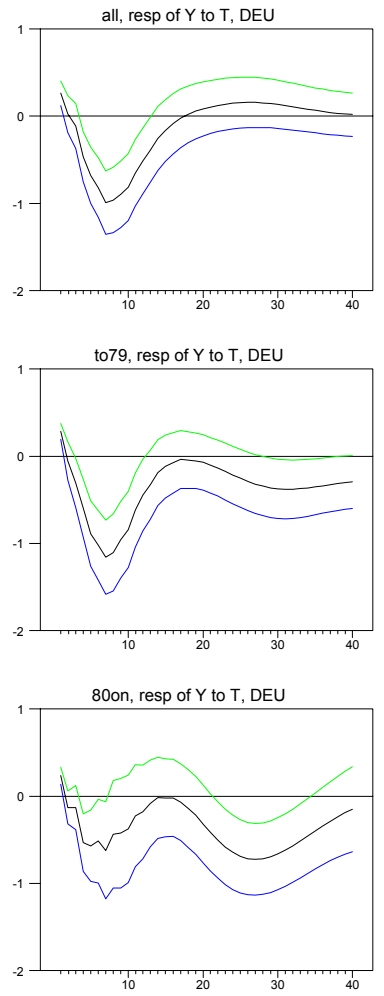
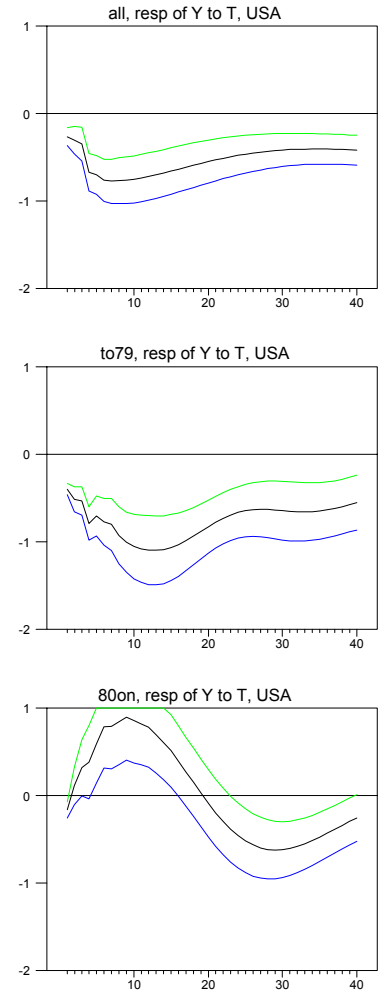
$\mathrm{F}$ ounded in 1983, the Centre for European Policy Studies is an independent policy research institute dedicated to producing sound policy research leading to constructive solutions to the challenges facing Europe today. Funding is obtained from membership fees, contributions from official institutions (European Commission, other international and multilateral institutions, and national bodies), foundation grants, project research, conferences fees and publication sales.

\section{GOALS}

- To achieve high standards of academic excellence and maintain unqualified independence.

- To provide a forum for discussion among all stakeholders in the European policy process.

- To build collaborative networks of researchers, policy-makers and business across the whole of Europe.

- To disseminate our findings and views through a regular flow of publications and public events.

\section{ASSETS AND ACHIEVEMENTS}

- Quality research by an international staff of 30 drawn from fifteen countries.

- An extensive network of external collaborators, including some 35 senior associates with extensive experience working in EU affairs.

- Complete independence to set its own priorities and freedom from any outside influence.

- Ability to anticipate trends and to analyse policy questions well before they become topics of general public discussion.

\section{Programme Structure}

CEPS is a place where creative and authoritative specialists reflect and comment on the problems and opportunities facing Europe today. This is evidenced by the depth and originality of its publications and the talent and prescience of its expanding research staff. The CEPS research programme is organised under two major headings:

\section{Economic Policy}

Macroeconomic Policy

European Network of Economic Policy

Research Institutes (ENEPRI)

Financial Markets and Institutions

European Credit Research Institute (ECRI)

Trade Developments and Policy

Energy for the $21^{\text {st }}$ Century

Efficiency in the Pursuit of Collective Goals

\section{Politics, Institutions and Security}

Political Institutions and Society

The Wider Europe

South East Europe

Caucasus and Black Sea

EU-Russian Relations

The CEPS-IISS Security Forum

South East European Security Cooperation

Justice and Home Affairs

In addition to these two sets of research programmes, the Centre organises a variety of activities within the CEPS Policy Forum. These include CEPS working parties, the lunchtime membership meetings, network meetings abroad, board-level briefings for CEPS corporate members, conferences, training seminars, major annual events (e.g. the CEPS International Advisory Council) and internet and media relations.

\section{Centre for European Policy Studies \\ 1 Place du Congrès \\ 1000 Brussels, Belgium}

Tel: 32(0)2.229.39.11 Fax: 32(0)2.219.41.51

E-mail: info@ceps.be Website: http://www.ceps.be 